\title{
Soil concentrations and soil-atmosphere exchange of alkylamines in a boreal Scots pine forest
}

\author{
Antti-Jussi Kieloaho ${ }^{1,2}$, Mari Pihlatie ${ }^{1,2}$, Samuli Launiainen ${ }^{3}$, Markku Kulmala ${ }^{2}$, Marja-Liisa Riekkola ${ }^{4}$, \\ Jevgeni Parshintsev $^{4}$, Ivan Mammarella ${ }^{2}$, Timo Vesala ${ }^{2,5}$, and Jussi Heinonsalo ${ }^{1}$ \\ ${ }^{1}$ University of Helsinki, Department of Food and Environmental Sciences, P.O. Box 56, 00014, Helsinki, Finland \\ ${ }^{2}$ University of Helsinki, Department of Physics, Division of Atmospheric Sciences, P.O. Box 68, 00014, Helsinki, Finland \\ ${ }^{3}$ Natural Resources Institute Finland, Environmental Impacts of Production, Latokartanonkaari 9, 00790, Helsinki, Finland \\ ${ }^{4}$ University of Helsinki, Department of Chemistry, Laboratory of Analytical Chemistry, P.O. Box 55, 00014, Helsinki, Finland \\ ${ }^{5}$ University of Helsinki, Department of Forest Sciences, P.O. Box 27, 00014, Helsinki, Finland \\ Correspondence to: Antti-Jussi Kieloaho (antti-jussi.kieloaho@helsinki.fi)
}

Received: 30 August 2016 - Discussion started: 5 September 2016

Revised: 20 January 2017 - Accepted: 24 January 2017 - Published: 8 March 2017

\begin{abstract}
Alkylamines are important precursors in secondary aerosol formation in the boreal forest atmosphere. To better understand the behavior and sources of two alkylamines, dimethylamine (DMA) and diethylamine (DEA), we estimated the magnitudes of soil-atmosphere fluxes of DMA and DEA using a gradient-diffusion approximation based on measured concentrations in soil solution and in the canopy air space. The ambient air concentration of DMA used in this study was a sum of DMA and ethylamine. To compute the amine fluxes, we first estimated the soil air space concentration from the measured soil solution amine concentration using soil physical (temperature, soil water content) and chemical $(\mathrm{pH})$ state variables. Then, we used the resistance analogy to account for gas transport mechanisms in the soil, soil boundary layer, and canopy air space. The resulting flux estimates revealed that the boreal forest soil with a typical long-term mean $\mathrm{pH} 5.3$ is a possible source of DMA $\left(170 \pm 51 \mathrm{nmol} \mathrm{m}^{-2} \mathrm{day}^{-1}\right)$ and a sink of DEA $\left(-1.2 \pm 1.2 \mathrm{nmol} \mathrm{m}^{-2} \mathrm{day}^{-1}\right)$. We also investigated the potential role of fungi as a reservoir for alkylamines in boreal forest soil. We found high DMA and DEA concentrations both in fungal hyphae collected from field humus samples and in fungal pure cultures. The highest DMA and DEA concentrations were found in fungal strains belonging to decay and ectomycorrhizal fungal groups, indicating that boreal forest soil and, in particular, fungal biomass may be important reservoirs for these alkylamines.
\end{abstract}

\section{Introduction}

Aerosols are important in cooling the atmosphere because they increase the scattering of sunlight and increase albedo through cloud formation. In boreal forests, volatile organic compounds emitted from the biosphere largely drive aerosol formation and aerosol growth to cloud condensation nuclei (Kulmala et al., 1998; Kerminen et al., 2010; Riipinen et al., 2012). Amines have been suggested to be key compounds in the aerosol formation process (Angelino et al., 2001; Silva et al., 2008; Kurtén et al., 2008; Smith et al., 2009; Yu et al., 2012; Almeida et al., 2013).

Amines are nitrogenous organic molecules in the form of $\mathrm{N}_{3}$, where $R$ denotes hydrogen or alkyl or aryl group. Low-weight alkylamines, which have one to six atom carbon chains bound to a nitrogen atom, are known to be degradation products of amino-acid-rich substrates, such as dairy or fish (Ge et al., 2011a). However, the origin of these amine compounds in natural environments is poorly understood. Sintermann and Neftel (2015) concluded that flowering of vegetation especially in springtime, and non-flowering vegetation during growing season are potential sources of alkylamines. Sintermann and Neftel (2015) suggested that the contribution of fungal sporocarps and decomposing organic matter as amine sources increases towards the autumn.

Low-weight alkylamines may be produced in soils during the degradation of organic $\mathrm{N}$ compounds, especially amino acid decarboxylation (Yan et al., 1996; Xu et al., 2006). Kim 


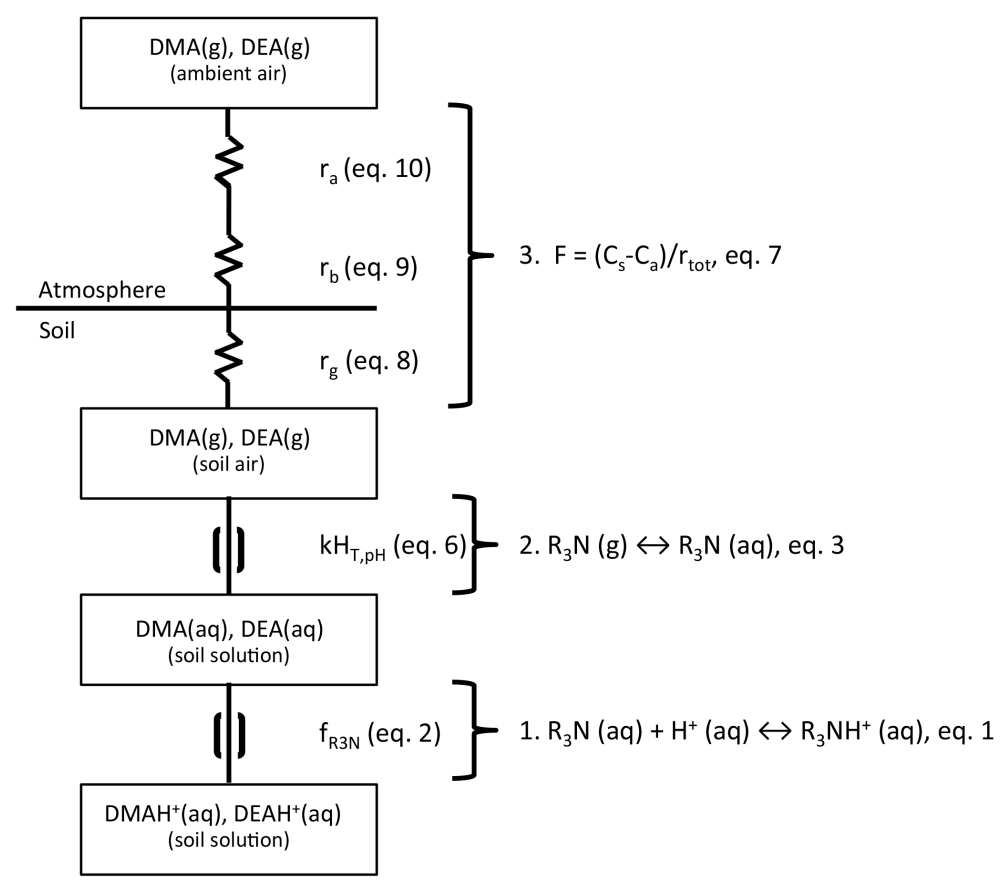

Figure 1. Scheme used for soil-atmosphere flux estimation of dimethylamine (DMA) and diethylamine (DEA) from reactions occurring in soil solution to transfer from soil air to ambient air. Boxes denote DMA and DEA concentrations in soil solution, soil air, and ambient air. Numbers denote for steps in the flux estimation. Step 1: acid-base reaction and protonation of alkylamine; step 2: partitioning of nonprotonated DMA and DEA between aqueous and gas phases; step 3: flux of DMA and DEA between soil and ambient air in which flux is determined by dividing concentration gradient by sum of component resistances (soil resistance, $r_{g}$; quasi-laminar boundary-layer resistance, $r_{\mathrm{b}}$; aerodynamic resistance, $\left.r_{\mathrm{a}}\right)$.

et al. (2001) and Rappert and Müller (2005) showed that quaternary ammonium compounds (e.g., carnitine, choline, and betaine), often present in soil solution (Warren, 2013, 2014), could be degraded to alkylamines (trimethylamine (TMA), dimethylamine (DMA), and monomethylamine) by the soil microbial community using both aerobic and anaerobic pathways. Sintermann and Neftel (2015) stated that decaying organic matter contains elevated levels of precursor substances for alkylamine production, hence indicating that decaying organic matter may be a source of alkylamines.

Concentrations of alkylamines in atmospheric particles and in gas phase are rarely reported from boreal ecosystems, despite the importance of amines in aerosol formation processes (Mäkelä et al., 2001; Smith et al., 2009; Kieloaho et al., 2013), mostly due to challenges in detecting these compounds. Mäkelä et al. (2001) reported elevated concentrations of dimethylaminium (protonated DMA) during particle formation periods in boreal forest. In our previous study (Kieloaho et al., 2013), we found the gas-phase alkylamines in boreal forest air, and we concluded that the seasonal variations in the atmospheric amine concentrations are linked to vegetation dynamics and soil activity.

Direct flux measurements of alkylamines are difficult to perform and are very rarely made (Sintermann and Neftel, 2015) due to the high reactivity of amines and lack of suit- able measurement techniques and instrumentation. However, the magnitude of fluxes can be indirectly estimated if the concentrations of the target compounds in different reservoirs (e.g., vegetation, soil, and atmosphere) are known. In general, the fluxes are driven by a concentration gradient between the reservoirs, such as ambient air and an aqueous solution. As follows, gas-phase concentration in soil air can be calculated by assuming equilibrium between the aqueous solution and the gas phase above the solution (Farquhar et al., 1980; Nemitz et al., 2000). Furthermore, the fluxes through a soil-atmosphere boundary can be estimated using a gradientdiffusion approximation, often presented by an electrical resistance analogy (Hicks et al., 1987; Seinfield and Pandis, 1998; Sutton et al., 1998).

In this study, we used three layers to estimate the potential exchange of two alkylamines, DMA and diethylamine (DEA), between soil and the atmosphere (Fig. 1). Amine concentrations in boreal forest soil and in fungal hyphae were measured and used to estimate potential fluxes of the selected alkylamines from a boreal Scots pine forest soil to the atmosphere. We hypothesize that by using soil amine concentration data and the resistance analogy, it is possible to estimate the potential sources and sinks of alkylamines in the soil. 


\section{Materials and methods}

\subsection{Study site and supplementary measurements}

Study site is a Scots pine forest at the SMEAR II station (Station for Measuring Forest Ecosystem - Atmosphere Relations) at Hyytiälä $\left(61^{\circ} 84^{\prime} \mathrm{N}, 24^{\circ} 26^{\prime} \mathrm{E}\right.$; $180 \mathrm{~m}$ a.s.l. $)$ in southern Finland (Hari and Kulmala, 2005). The forest stand at the SMEAR II station is approximately 50 years old and dominated by Scots pine (Pinus sylvestris L.), with Norway spruce (Picea abies (L.) H. Karst.), birch (Betula L. spp.), and European aspen (Populus tremula L.) found occasionally in the understory. The most common plant species at the ground level are bilberry (Vaccinium myrtillus.), lingonberry (Vaccinium vitis-idaea L.), wavy hairgrass (Deschampsia flexuosa (L.) Trin.), and heather (Calluna vulgaris (L.) Hull.). The most common mosses are Schreber's big red stem moss (Pleurozium schreberi (Brid.) Mitt.) and a dicranum moss (Dicranum Hedw. sp.) (Ilvesniemi et al., 2009). The soil at the site is Haplic podzol on glacial till, with an average depth of $0.5-0.7 \mathrm{~m}$.

A half-hour average of soil water content (at $0.05 \mathrm{~m}$ ), soil temperature (at $0.05 \mathrm{~m}$ ), and above-canopy (at $23 \mathrm{~m}$ ) friction velocity was used in the calculations of DMA and DEA equilibrium gas-phase concentrations in soil air and to calculate DMA and DEA soil-atmosphere exchange. Soil temperature was measured using PT-100 resistance thermometers, and soil water content was measured with a time-domain reflectometer (TDR 100; Campbell Scientific Inc., Logan, UT, USA). A mean $\mathrm{pH}$ value of 5.3 measured over 14 years and sampled once per month during a snow-free period from three replicate suction cup lysimeters at $2 \mathrm{~cm}$ depth in the mineral soil was used. The 10th and 90th percentiles of the soil $\mathrm{pH}$ were 4.5 and 6.0 , respectively.

The ambient air concentrations of DMA, ethylamine (EA), and DEA were measured at $2 \mathrm{~m}$, below the overstory canopy (Kieloaho et al., 2013), and used in the flux estimation. The analytical procedure was incapable of resolving DMA and EA, and therefore only the sum of these compounds is reported and later referred to as DMA concentration. The DMA + EA and DEA air concentration measurements were conducted from May 2011 to October 2011 by collecting weekly air samples into phosphoric acid impregnated glass fiber filters described in detail in Kieloaho et al. (2013). Measured ambient air concentrations of DMA + EA varied from 0.49 to $6.4 \mathrm{nmol} \mathrm{m}^{-3}$, and the mean observed air concentration with standard deviation was $1.7 \pm 1.2 \mathrm{nmol} \mathrm{m}^{-3}$ (Kieloaho et al., 2013). The highest concentration of DMA + EA $\left(6.4 \pm 0.83 \mathrm{nmol} \mathrm{m}^{-3}\right)$ was measured in October. Ambient air concentration of DEA varied from 0.02 to $0.63 \mathrm{nmol} \mathrm{m}^{-3}$, the mean being $0.26( \pm 0.22) \mathrm{nmol} \mathrm{m}^{-3}$ (Kieloaho et al., 2013).

\subsection{Soil and fungal hyphae samples}

Soil samples were collected at same time in May 2011. The first soil samples were used to screen the concentrations of amines in the humus layer, mineral soil, and visible fungal hyphae. A $10 \mathrm{~L}$ sample of the humus layer (F/H-horizon) and a $5 \mathrm{~L}$ sample from the underlying mineral $\mathrm{B}$-horizon were collected. The soil was homogenized and stored at $+4{ }^{\circ} \mathrm{C}$ (for about day) until three $2 \mathrm{~mL}$ samples of mineral soil, humus layer, and visible fungal rhizomorphic hyphae were collected.

The second soil samples were stored at $+4{ }^{\circ} \mathrm{C}$ until used in the greenhouse experiment where the effects of soil organic matter decomposing enzymes on nitrogen turnover processes were studied (Kieloaho et al., 2016). The soil samples were extracted with $1 \mathrm{M} \mathrm{KCl}$ and analyzed for low-molecularweight amines as described in Sect. 2.3.

In total 19 different fungal strains, representing 14 different ascomycete and basidiomycete fungal species were grown one by one for 6 weeks in LN-AS media containing axenic liquid cultures (Bäck et al., 2010). The strains were divided into four functionally distinct groups, ectomycorrhiza, ericoid mycorrhiza, endophytes, and decay fungi, based on their sequence identification. Individual strains used in this study are listed in Table S2 in the Supplement.

Fungal biomass was collected from the liquid cultures using a Miracloth filter, rinsed with distilled water, and stored at $-20^{\circ} \mathrm{C}$ until extracted and analyzed for amines. Agar plugs and the growth media, used for fungal inoculation in flask cultures, were analyzed separately for amine concentrations as negative controls.

\subsection{Low-molecular-weight amine analysis}

Fungal biomass samples and the first set of soil samples were extracted by dynamic sonication assisted extraction for 20 min with flow rate of $0.5 \mathrm{~mL} \mathrm{~min}^{-1}$ (1\% aqueous acetic acid-acetonitrile, $1: 1)$. Samples inserted in extraction chambers made of polyether ether ketone (PEEK, $5 \mathrm{~cm}$ length, i.d. $7.5 \mathrm{~mm}$ ) equipped with screw caps. After extraction, samples were filtered through the $0.45 \mu \mathrm{m}$ syringe filters. Extraction solvent was pumped through the extraction chambers, which were immersed in ultrasonic bath (Branson Sonifier S-250 A, Branson, Danbury, CT, USA) using Jasco PU-980 HPLC pumps (Jasco Corp., Easton, MD, USA).

The samples were statically extracted for $30 \mathrm{~min}$. Mineral and humus soil samples, 21.8 and $16.2 \mathrm{~g}$ of fresh weight, respectively, were extracted by sonication with $40 \mathrm{~mL}$ dichloromethane-methanol $(1: 1)$ together with $1 \mathrm{~mL}$ $1 \mathrm{M} \mathrm{HCl}$ for $30 \mathrm{~min}$. Also, $700 \mathrm{mg}$ fresh weight of fungal hyphae samples was weighed and extracted with $10 \mathrm{~mL}$ of the extraction solvent with addition of $100 \mu \mathrm{L} 1 \mathrm{M} \mathrm{HCl}$. After the extraction, the fungal and mineral soil samples were evaporated to $5 \mathrm{~mL}$ and humus soil sample to $15 \mathrm{~mL}$ and then filtered through $0.45 \mu \mathrm{m}$ acetyl cellulose syringe filters. 
Low-molecular-weight alkylamines in extracts from soil, soil fungal hyphae, and fungal pure cultures were analyzed with the analytical method introduced by Ruiz-Jiminez et al. (2012). Soil extracts and cultured fungal biomass extracts were first dansylated. Since dansylated amines are relatively unstable, derivatized samples were analyzed immediately or within $24 \mathrm{~h}$. Acetaminophen was used as an internal standard (the final concentration of the standard was $1 \mathrm{ng}$ at the detector). The derivatization procedure tends to overestimate amine concentrations but the estimations of the relative amounts to the internal standard of amines are presumed to be accurate (Ruiz-Jiminez et al., 2012).

Analysis of the samples was performed with an Agilent 1260 Infinity liquid chromatograph coupled via electrospray ionization to an Agilent 6420 triple quadrupole mass spectrometer (Agilent Technologies, Santa Clara, CA, USA). The initial mobile phase was a mixture of $50 \%$ A (water acidified with $1 \%$ acetic acid) and $50 \%$ B (acetonitrile). Sample volume of $20 \mu \mathrm{L}$ was injected and a linear gradient to $100 \%$ $\mathrm{B}$ in $10 \mathrm{~min}$ was applied. After $7 \mathrm{~min}$ in $100 \% \mathrm{~B}$, mobile phase was decreased to $50 \% \mathrm{~B}$ in $1 \mathrm{~min}$. The column was let to equilibrate before the next injection for $7 \mathrm{~min}$ in $50 \%$ of B. A Hibar HR column (Purosphere, RP-18, endcapped, $2 \mu \mathrm{m}, 50 \mathrm{~mm} \times 2.1 \mathrm{~mm}$, Merck, Darmstadt, Germany) was used and the temperature was kept at $40^{\circ} \mathrm{C}$. Ionization parameters were as follows: drying gas (nitrogen) temperature of $300^{\circ} \mathrm{C}$, gas flow of $7.5 \mathrm{~L} \mathrm{~min}^{-1}$, and nebulizer (nitrogen) of 35 psi. MS1 and MS2 heaters were kept at $100^{\circ} \mathrm{C}$. The dynamic multiple reaction monitoring acquisition method was applied. MassHunter Quantitative Analysis software B.04.00 was used for data processing.

To identify amines in the samples the following external standards were used: isopropylaniline, tripropylamine, 2amino-1-butanol, DL-2-aminobutyric acid, and diethylamine for the first field soil samples and the soil fungal hyphae and methylamine, dimethylamine, ethanolamine, diethylamine, dibutylamine, and sec-butylamine for the second soil samples (Kieloaho et al., 2016) and for pure fungal culture strains.

\subsection{Concentrations of DMA and DEA in soil air}

The concentrations of DMA and DEA in soil solution (aq.) are obtained from the measurements in the greenhouse experiment on boreal forest soil (Kieloaho et al., 2016) and assumed to be constant during the whole study period. The DMA and DEA concentrations in soil solution were 92.3 and $0.296 \mu \mathrm{mol} \mathrm{L}^{-1}$, respectively.

The concentrations of non-dissociated DMA and DEA are calculated from the measured soil solution concentrations based on reversible acid-base reaction:

$R_{3} \mathrm{~N}(\mathrm{aq})+\mathrm{H}^{+}(\mathrm{aq}) \leftrightarrow R_{3} \mathrm{NH}^{+}(\mathrm{aq})$,

where $R_{3} \mathrm{~N}$ is non-dissociated amine molecule and $R$ denotes either methyl or ethyl organic side group or hydrogen atom.
The dissociation reaction reaches a temperature-dependent equilibrium, which is independent of reactant and reaction product concentrations.

A concentration in soil solution is a sum of nondissociated $\left(R_{3} \mathrm{~N}\right)$ and dissociated $\left(R_{3} \mathrm{NH}^{+}\right)$forms of amines. In the first step, using equilibrium thermodynamic principles, the fraction $\left(f_{R_{3} \mathrm{~N}}\right)$ of total amine concentration present as non-dissociated form can be estimated (Montes et al., 2009) when the activity of $R_{3} \mathrm{~N}$ and $R_{3} \mathrm{NH}^{+}$assumed to be equal. The activity of protons $\left[\mathrm{H}^{+}\right]$in soil solution is based on the measured $\mathrm{pH}$ values. Equilibrium dissociation coefficients $\left(p K_{\mathrm{a}}\right)$ for DMA and DEA are 10.3 and 10.5, respectively, and $K_{\mathrm{a}}$ is a negative logarithm of $p K_{\mathrm{a}}$ :

$f_{R_{3} \mathrm{~N}}=\frac{\left[R_{3} \mathrm{~N}\right]}{\left[R_{3} \mathrm{~N}\right]+\left[R_{3} \mathrm{NH}^{+}\right]}=\frac{1}{1+\frac{\left[\mathrm{H}^{+}\right]}{K_{\mathrm{a}}}}$.

In the second step, the non-dissociated DMA and DEA are partitioned between aqueous phases and soil air:

$R_{3} \mathrm{~N}(\mathrm{aq}) \leftrightarrow R_{3} \mathrm{~N}(g)$.

According to Henry's law, the solubility of non-dissociated gas in a solution is directly proportional to the partial pressure of the gas above the solution

$k_{\mathrm{H}}=\frac{c_{R_{3} \mathrm{~N}}}{p_{\text {soil }}}$,

where $k_{\mathrm{H}}$ is Henry's law coefficient, $c_{R_{3} \mathrm{~N}}$ is non-dissociated aqueous phase concentration, and $p_{\text {soil }}$ is a partial pressure of alkylamines in soil gas phase. Due to temperature dependence, acid dissociation $\left(K_{\mathrm{a}}\right)$ and Henry's law coefficients were corrected for temperature by Van 't Hoff equation:

$k_{(\mathrm{T})}=k_{1} e^{\frac{-\delta H^{\circ}}{R\left(\mathrm{~T}_{2}^{-1}-\mathrm{T}_{1}^{-1}\right)}}$,

where $k_{(\mathrm{T})}$ is the temperature-corrected coefficient, $k_{1}$ is the coefficient to be corrected, $\delta H^{\circ}$ is the enthalpy change in reaction or phase transition, $R$ is the molar gas constant, and $T_{1}$ and $T_{2}$ are temperatures in Kelvin. To take into an account the effect of acid dissociation on the partitioning of DMA or DEA between the aqueous and gas phases, a temperaturecorrected acid dissociation coefficient was used to calculate the effective Henry's law coefficients according to Seinfield and Pandis (2006):

$k_{\mathrm{H}(\mathrm{T}, \mathrm{pH})}=k_{\mathrm{H}(\mathrm{T})}\left(\frac{1+\left[\mathrm{H}^{+}\right]}{K_{\mathrm{a}(\mathrm{T})}}\right)$,

where $k_{\mathrm{H}(\mathrm{T})}$ is the temperature-corrected Henry's law coefficient, $\left[\mathrm{H}^{+}\right]$is measured proton concentration of aqueous phase, and $K_{\mathrm{a}(\mathrm{T})}$ is the temperature-corrected acid dissociation coefficient.

Henry's law coefficient, the acid dissociation coefficient, the acid dissociation reaction and phase change energies were retrieved for DMA and DEA from National Institute of Standards and Technology Chemistry WebBook (Linstrom and Mallard, 2014). 


\subsection{Estimation of soil-air fluxes of DMA and DEA}

The soil-air fluxes $\left(F, \mathrm{nmol} \mathrm{m}^{-2} \mathrm{day}^{-1}\right)$ of DMA and DEA were estimated using flux-gradient relationship (Fig. 1) as

$F=\frac{C_{\mathrm{s}}-C_{\mathrm{a}}}{r_{\mathrm{tot}}}$,

where $C_{\mathrm{s}}$ and $C_{\mathrm{a}}$ are concentrations $\left(\mathrm{nmol} \mathrm{m}^{-3}\right)$ in the soil air space and in the atmosphere at $2.0 \mathrm{~m}$ above the forest floor, respectively, and $r_{\text {tot }}\left(\mathrm{s} \mathrm{m}^{-1}\right)$ is the total gas transport resistance, which includes soil resistance $\left(r_{g}\right)$, quasi-laminar boundary-layer resistance $\left(r_{\mathrm{b}}\right)$, and aerodynamic resistance $\left(r_{\mathrm{a}}\right)$ in series.

In soil, the gas transport is dominated by molecular diffusion though the air-filled part of soil matrix. The soil resistance $\left(r_{g}, \mathrm{~s} \mathrm{~m}^{-1}\right)$ in the organic soil layer of depth $\Delta z_{\mathrm{s}}$ (here $0.05 \mathrm{~m}$ ) is estimated as

$r_{g}=\frac{\Delta z_{\mathrm{s}}}{D_{p}}=\frac{\Delta z_{\mathrm{s}}}{D_{o} \theta_{\mathrm{a}}{ }^{b}}$,

where the molecular diffusivity in soil $D_{p}$ is computed from the molecular diffusivity in free air $\left(D_{o}\right)$, using air-filled porosity $\left(\theta_{\mathrm{a}}\right)$ to account for the reduced cross-sectional area and increased path length in the soil relative to free air. The parameter $b=1.1$ as reported for humus layer in Glinski and Stepnieswski (1985).

The transport through the quasi-laminar boundary layer at the soil surface is described by the soil boundary-layer resistance $\left(r_{\mathrm{b}}, \mathrm{s} \mathrm{m}^{-1}\right)$ following Schuepp (1977):

$r_{\mathrm{b}}=\frac{S c-\ln \left(\delta_{o} / z_{1}\right)}{k_{\mathrm{v}} u_{* \mathrm{~g}} z_{1}}$,

where $S c$ is the Schmidt number, $k_{\mathrm{v}}(\sim 0.41)$ is the von Kármán constant, $u_{* \mathrm{~g}}$ is the near-ground friction velocity, the height above the ground, where the molecular diffusivity and turbulent transport efficiency are equal, is $\delta_{o}=D_{o} / k_{\mathrm{v}} u_{* \mathrm{~g}}$, and $z_{1}$ is the height below which the wind profile is assumed logarithmic. The model for $r_{\mathrm{b}}$ applied here is identical to that used to compute gas transfer, e.g., in Baldocchi (1988), Nemitz et al. (2001), and Launiainen et al. (2013).

The aerodynamic resistance $\left(r_{\mathrm{a}}\right)$ accounts for the turbulent gas transport between the soil surface and concentration measurement height $\left(z_{\mathrm{m}}\right)$ in the canopy air space. The $r_{\mathrm{a}}$ is calculated by integrating the inverse of eddy diffusivity $\left(K_{\mathrm{S}}\right.$, $\mathrm{m}^{2} \mathrm{~s}^{-1}$ ) over the layer as in Baldocchi (1988):

$r_{\mathrm{a}}=\int_{0 \mathrm{~m}}^{z} \frac{1}{K_{\mathrm{S}}(z)} \mathrm{d} z$.

The profile of $K_{\mathrm{s}}(z)$ within the canopy and the value of $u_{* \mathrm{~g}}$ needed for computing $r_{\mathrm{a}}$ and $r_{\mathrm{b}}$, are provided by a first-order closure model for momentum exchange within the canopy as in Launiainen et al. (2013, 2015). As shown in Supplement $\mathrm{B}$, the model computes mean velocity, momentum flux $\left(\overline{u^{\prime} w^{\prime}}\right)$, and $K_{\mathrm{s}}$ profiles from local balance of momentum absorption and canopy drag, neglecting the effects of atmospheric stability. The latter have been shown modest for below-canopy flow statistics at the SMEAR II site (Launiainen et al., 2007).

For DMA and DEA flux estimates, the measured weekly mean ambient air concentrations and their standard deviations (Kieloaho et al., 2013) were used. Soil air concentrations and total resistances were obtained from the calculated half-an-hour values and averaged to weekly means and their weekly standard deviations. Gaussian error propagation was used to estimate the error of flux estimate with an assumption that errors of concentration gradient $\left(C_{\mathrm{gr}}=C_{\mathrm{s}}-C_{\mathrm{a}}\right)$ and total resistance $\left(r_{\text {tot }}\right)$ are independent from each other. The error, expressed as standard deviation of soil flux $\left(F_{\mathrm{SD}}\right)$, was calculated from normalized standard deviations of $C_{\mathrm{gr}}$ and $r_{\mathrm{tot}}$ :

$$
F_{\mathrm{SD}}=F \sqrt{\left(\frac{C_{\mathrm{gr}, \mathrm{SD}}}{C_{\mathrm{gr}}}\right)^{2}+\left(\frac{r_{\mathrm{tot}, \mathrm{SD}}}{r_{\mathrm{tot}}}\right)^{2}} .
$$

\subsection{Chemical reaction and turbulent transport timescales}

Ratio between turbulent transport timescale and chemical reaction timescale (Damköhler number, DA) is a measure of flux divergence due to chemical reactions occurring in the ambient air. As DMA and DEA are reactive gases,

$\mathrm{DA}=\frac{\tau_{\mathrm{tr}}}{\tau_{\mathrm{ch}}}$

was calculated for both to compare their atmospheric lifetimes $\left(\tau_{\mathrm{ch}}\right)$ to characteristic turbulent timescale $\tau_{\mathrm{tr}}=r_{\mathrm{a}} / z_{\mathrm{m}}$, which is associated with transport between the soil and the atmosphere, in this case the within-canopy measurement height. DMA and DEA mainly react in the atmosphere with hydroxyl $(\mathrm{OH})$ radicals, and the chemical timescales $\tau_{\text {ch }}$ for DMA and DEA are 3.2 and $2.6 \mathrm{~h}$, respectively (Héllen et al., 2014). DA smaller than unity indicates that chemical reactions play a minor role in linking measured flux at a given height to sinks and sources below the measurement height (Rinne et al., 2012). When DA is smaller than 0.1, the role of chemical reactions is typically neglected in flux estimates (Rinne et al., 2012).

\subsection{Sensitivity analysis}

The sensitivities of the calculated resistances and estimated soil air concentrations and soil fluxes were assessed by oneat-a-time method by studying the effect of the measured variable on the calculated variable. In case of soil air concentrations, the studied variables were $\mathrm{pH}$ (from 4.0 to 6.0 ), temperature (from 0 to $20^{\circ} \mathrm{C}$ ), and soil solution concentration (from 0 to $100 \mu \mathrm{mol} \mathrm{L}^{-1}$ ), as these variable have an effect on dissociation and separation between gas and aqueous phases of DMA and DEA. The measured soil solution concentrations were based on $1 \mathrm{M} \mathrm{KCl}$ extractions. The soil solution 
Table 1. The mean dimethylamine and diethylamine concentrations ( $\mu \mathrm{g} \mathrm{g}^{-1}$ fresh weight) and their standard deviations in the field samples, different fungal functional groups, and in the humus soil in a greenhouse experiment.

\begin{tabular}{lrr}
\hline & Dimethylamine (DMA) & Diethylamine (DEA) \\
\hline Field samples & $\mu \mathrm{g} \mathrm{g}^{-1} \mathrm{FW}$ & $\mu \mathrm{g} \mathrm{g}^{-1} \mathrm{FW}$ \\
\hline Soil fungal hyphae & $\mathrm{n.m.}^{\mathrm{a}}$ & 2.9 \\
Humus soil & n.m. & 0.3 \\
Mineral soil & n.m. & $<0.01$ \\
\hline Pure culture samples & & \\
\hline Ectomycorrhiza & $116( \pm 34)$ & $2.5( \pm 0.9)$ \\
Ericoid mycorrhiza & $80( \pm 18)$ & $1.9( \pm 0.5)$ \\
Endophyte & $25( \pm 12)$ & $0.49( \pm 0.23)$ \\
Decay fungi & $360( \pm 320)$ & $6.8( \pm 5.9)$ \\
Control agar media & 4.3 & 0.13 \\
\hline Experimental samples & & \\
\hline Humus soil (with plant) & & $0.03( \pm 0.02)$ \\
Humus soil (without plant) & $4.3( \pm 3.9)$ & $0.02( \pm 0.01)$ \\
Mean of humus soil & $6.7( \pm 2.2)$ & $0.02( \pm 0.02)$ \\
\hline
\end{tabular}

${ }^{a}$ n.m. indicates not measured. ${ }^{b}$ Kieloaho et al. (2016).

concentration of DMA was used as the upper limit for the soil solution concentration range.

The effects of environmental variables on resistances were assessed separately for $r_{g}, r_{\mathrm{b}}$, and $r_{\mathrm{a}}$. In case of the $r_{g}$, effect of soil water content (from 0.1 to $0.45 \mathrm{~m}^{3} \mathrm{~m}^{-3}$ ) was assessed due to its effect on soil spore space continuum. In addition, soil temperature (from 0 to $25^{\circ} \mathrm{C}$ ) and soil depth (from 0 to $0.15 \mathrm{~m}$ ) were studied as they affect diffusion and the length of the diffusion pathway. For $r_{\mathrm{b}}$, the effects of temperature (from 0 to $25^{\circ} \mathrm{C}$ ) and friction velocity (from 0.1 to $0.15 \mathrm{~m} \mathrm{~s}^{-1}$ ) were assessed as they have effects on diffusion and thickness of quasi-laminar layer, respectively. In case of $r_{\mathrm{a}}$, the effect of friction velocity (from 0.1 to $0.15 \mathrm{~m} \mathrm{~s}^{-1}$ ) was studied as it determines the effectiveness of turbulent transport.

The weekly ambient air concentration measurements neglect potential diurnal variation of the studied alkylamines. To assess whether this significantly affects the estimated DMA and DEA fluxes, two different sinusoidal diurnal cycles were introduced. The first scenario assumes the diurnal cycle follows that of air temperature, as suggested for NH3 and TMA in a forest site in Alabama (USA) (You et al., 2014). The second scenario assumes that diurnal cycle of amines behaves as observed for monoterpenes at the site of our study (Hakola et al., 2012). Consequently, the minimum concentrations were assumed to occur at 04:00 and 14:00 EEST (UTC + 3), respectively, and the diurnal amplitude of ambient air concentrations was set to be twice the measured weekly concentration.

\section{Results}

\subsection{Amine contents in soil, soil-derived fungal hyphae, and pure fungal cultures}

Concentrations of DEA in humus soil and in fungal hyphae restricted from the humus were 0.3 and $2.9 \mu \mathrm{g} \mathrm{g}^{-1} \mathrm{FW}$ (Table 1), respectively. Amine concentrations in the mineral soil were below the detection limit of $0.01 \mu \mathrm{g} \mathrm{g}^{-1} \mathrm{FW}$. DMA was not measured from field samples, as it was not included in standards used for the first soil samples. The results for other amine compounds (2-amino-1-butanol and DL-2-aminobutyric acid) analyzed from field samples are presented in the Supplement (Table S1).

The highest DMA and DEA concentrations in the fungal pure cultures were measured in the decay fungi (Table 1). DMA concentrations were much higher than those of DEA throughout the all functional groups, and concentration of DMA varied from $25 \mu \mathrm{g} \mathrm{g}^{-1} \mathrm{FW}$ in endophytic fungi to $360 \mathrm{\mu g} \mathrm{g}^{-1} \mathrm{FW}$ in decay fungi. Three out of the four fungal strains that contain the most amine belonged to ectomycorrhiza. DEA concentrations in soil fungal hyphae $\left(2.9 \mu \mathrm{g} \mathrm{g}^{-1} \mathrm{FW}\right)$, ectomycorrhiza $\left(2.5 \mu \mathrm{g} \mathrm{g}^{-1} \mathrm{FW}\right)$ and ericoid mycorrhiza $\left(1.9 \mu \mathrm{g} \mathrm{g}^{-1} \mathrm{FW}\right)$ were in a similar range, while the concentrations in humus and mineral soil were markedly lower (Table 1). Amine concentrations of DMA and DEA and other measured amines (methylamine, ethanolamine, sec-butylamine, and dibutylamine) of individual strains, as well as the mean amine concentrations of ecological fungal groups, are shown in the Supplement (Tables S2 and S3, respectively). 


\subsection{Estimated soil air concentrations}

Over the study period, the estimated mean soil air concentrations of DMA and DEA with standard deviation, at mean soil $\mathrm{pH}$ (5.3), were $27 \pm 5.1$ and $0.032 \pm 0.006 \mathrm{nmol} \mathrm{m}^{-3}$, respectively. The effect of soil temperature, soil $\mathrm{pH}$, and soil solution concentration on amine concentrations in soil air is shown in Fig. 3. The soil air concentration follows the seasonal trend in soil temperature (Fig. 2). For DMA, the mean soil air concentration was higher than the measured mean ambient air concentration $\left(1.7 \mathrm{nmol} \mathrm{m}^{-3}\right)$ during the study period. For DEA, the mean soil air concentration was lower than the measured ambient air concentration $\left(0.26 \mathrm{nmol} \mathrm{m}^{-3}\right)$.

Sensitivity of estimated soil air concentration to soil solution concentration was assessed using a soil solution concentration range from 0 to $100 \mu \mathrm{mol} \mathrm{L}^{-1}$. Soil air concentration changed linearly in the studied range $29 \mathrm{nmol} \mathrm{m}^{-3}$ for DMA and $11 \mathrm{nmol} \mathrm{m}^{-3}$ for DEA (Fig. 3a).

Soil air concentrations of DMA and DEA are highly sensitive to soil $\mathrm{pH}$. The nonlinear relationship is caused by $\mathrm{pH}$ dependency of dissociation of an alkylamine in soil solution (Eq. 2) and partition of an alkylamine between aqueous solution and gas phase (Eq. 6).

In the measured range soil air concentration change was $680 \mathrm{nmol} \mathrm{m}^{-3}$ for DMA and 0.81 for DEA (Fig. 3c). Soil air concentrations in $\mathrm{pH} 4.0$ were $0.07 \mathrm{nmol} \mathrm{m}^{-3}$ for DMA and less than $0.01 \mathrm{nmol} \mathrm{m}^{-3}$ for DEA. In $\mathrm{pH}$ 5.1, soil air concentrations for the both compounds start to increase rapidly from $10 \mathrm{nmol} \mathrm{m}^{-3}$ for DMA and from $0.01 \mathrm{nmol} \mathrm{m}^{-3}$ for DEA to soil air concentrations in $\mathrm{pH} 6.0,680 \mathrm{nmol} \mathrm{m}^{-3}$ for DMA and $0.81 \mathrm{nmol} \mathrm{m}^{-3}$ for DEA.

Soil temperature had a minor effect on soil air concentrations than $\mathrm{pH}$ in assessed ranges. The concentration change in the temperature range was $24 \mathrm{nmol} \mathrm{m}^{-3}$ for DMA and $0.03 \mathrm{nmol} \mathrm{m}^{-3}$ for DEA (Fig. 3b). Sensitivity of soil air concentration was not assessed for soil water content because it has an effect only to the transport of DMA and DEA through the soil.

Estimated soil air concentration did not correlate with measured ambient air concentration in case of DMA $(r=0.09, p=0.68)$, but it correlated in case of DEA $(r=0.67, p<0.01)$ (Fig. 7a and b, respectively).

\subsection{Resistances and chemical reaction timescale}

The mean total resistance for the soil-air pathway $\left(r_{\text {tot }}\right)$ was $13500( \pm 2300) \mathrm{s} \mathrm{m}^{-1}$ for DMA and $18500( \pm 3200) \mathrm{s} \mathrm{m}^{-1}$ for DEA. The $r_{\text {tot }}$ was dominated, i.e., the transfer of the studied amines mostly limited, by slow diffusion of through the soil matrix (soil resistance, $r_{g}$ ). The mean soil resistance of both gases was $\sim 14000 \mathrm{~s} \mathrm{~m}^{-1}$ (Fig. 4b), hence being 1 and 2 orders of magnitude larger than quasi-laminar resistance $\left(r_{\mathrm{b}}, 1200 \mathrm{~s} \mathrm{~m}^{-1}\right)$ and aerodynamic resistance $\left(r_{\mathrm{a}}, 110 \mathrm{~s} \mathrm{~m}^{-1}\right)$, respectively (Fig. 4c).
Sensitivity of each resistance component to environmental variables (soil water content, temperature, and friction velocities and, in the case of $r_{g}$, organic soil depth) was assessed separately (Fig. S2 in the Supplement). In short, $r_{g}$ increases linearly with length of the diffusion pathway $\left(\Delta z_{\mathrm{s}}\right)$ and nonlinearly with increasing soil water content (Eq. 8). The temperature sensitivities of $r_{g}$ and $r_{\mathrm{b}}$ are weak in the studied temperature range and caused by weak decrease of molecular diffusivity with temperature. The $r_{\mathrm{b}}$ (Eq. 9) and $r_{\mathrm{a}}$ both decrease nearly order of magnitude when the above-canopy friction velocity increases from 0.1 to $1.5 \mathrm{~m} \mathrm{~s}^{-1}$, while the $r_{b}$ to $r_{\mathrm{a}}$ ratio is quasi-conserved. Most of the nonlinear decrease of $r_{\mathrm{b}}$ and $r_{\mathrm{a}}$ occurs at $u_{*}$ below $0.5 \mathrm{~m} \mathrm{~s}^{-1}$ (Fig. S2).

For DMA, DA ranged from 0.013 to 0.026 and having a mean of $0.019( \pm 0.004)$. For DEA, DA ranged from 0.017 to 0.033 with a mean of 0.023 ( \pm 0.005 ). Due to DA numbers lower than 0.1 the removal of DMA and DEA by chemical reactions in the canopy air space can be considered negligible for the flux estimates.

\subsection{Estimated soil fluxes}

The mean soil-atmosphere fluxes of DMA and DEA over May to November 2011 measurement period were $170( \pm 51)$ and $-1.2( \pm 1.2) \mathrm{nmol} \mathrm{m}^{-2}$ day $^{-1}$, respectively (Table 2). The DMA flux increased from the spring to summer and then decreased in the autumn. Unlike in the ambient air concentrations (Fig. 2b), there was no autumnal peak in the estimated DMA fluxes (Fig. 5). The seasonal pattern in DEA flux did not follow the changes in soil temperature or moisture, and the fluxes were negative most of the measurement period. Several strong and distinct DEA uptake periods were estimated in June, August, and October (Fig. 5).

Effects of environmental variables $(\mathrm{pH}$, temperature, soil water content, soil depth, and friction velocity) on estimated soil fluxes are shown in Fig. 6. A linear increase in soil solution concentration would increase flux from soil to the atmosphere linearly (Fig. 6a). The pH has a strong effect in the partitioning of DMA and DEA between aqueous and gas phases (Fig. 3c), and thus also in the flux estimates (Fig. 6b). The fluxes computed for 10th and 90th percentiles of measured soil $\mathrm{pH}(4.5$ and 6.0 , respectively) were $-0.67( \pm 0.68)$ and $4500( \pm 1300) \mathrm{nmol} \mathrm{m}^{-2} \mathrm{day}^{-1}$ for DMA and $-1.4( \pm 1.2)$ and $2.7( \pm 1.0) \mathrm{nmol} \mathrm{m}^{-2}$ day $^{-1}$ for DEA, respectively (Table 2).

According to the sensitivity analysis, both amines reach a zero flux point below which the emission from the soil will turn into an uptake to the soil in the measured $\mathrm{pH}$ range from 4.5 to 6.0. This turning point (compensation point with respect to $\mathrm{pH}$ ) occurred at $\mathrm{pH} 5.7$ for DEA and at $\mathrm{pH} 4.7$ for DMA was (Fig. 6b). A $10 \%$ decrease in soil solution concentration of DMA increased the turning point $\mathrm{pH}$ by 0.1 and similarly an increase in soil solution concentration of DMA decreased the turning point by $0.1 \mathrm{pH}$ unit. The turning point of DEA was less affected by the soil solution concentration. 

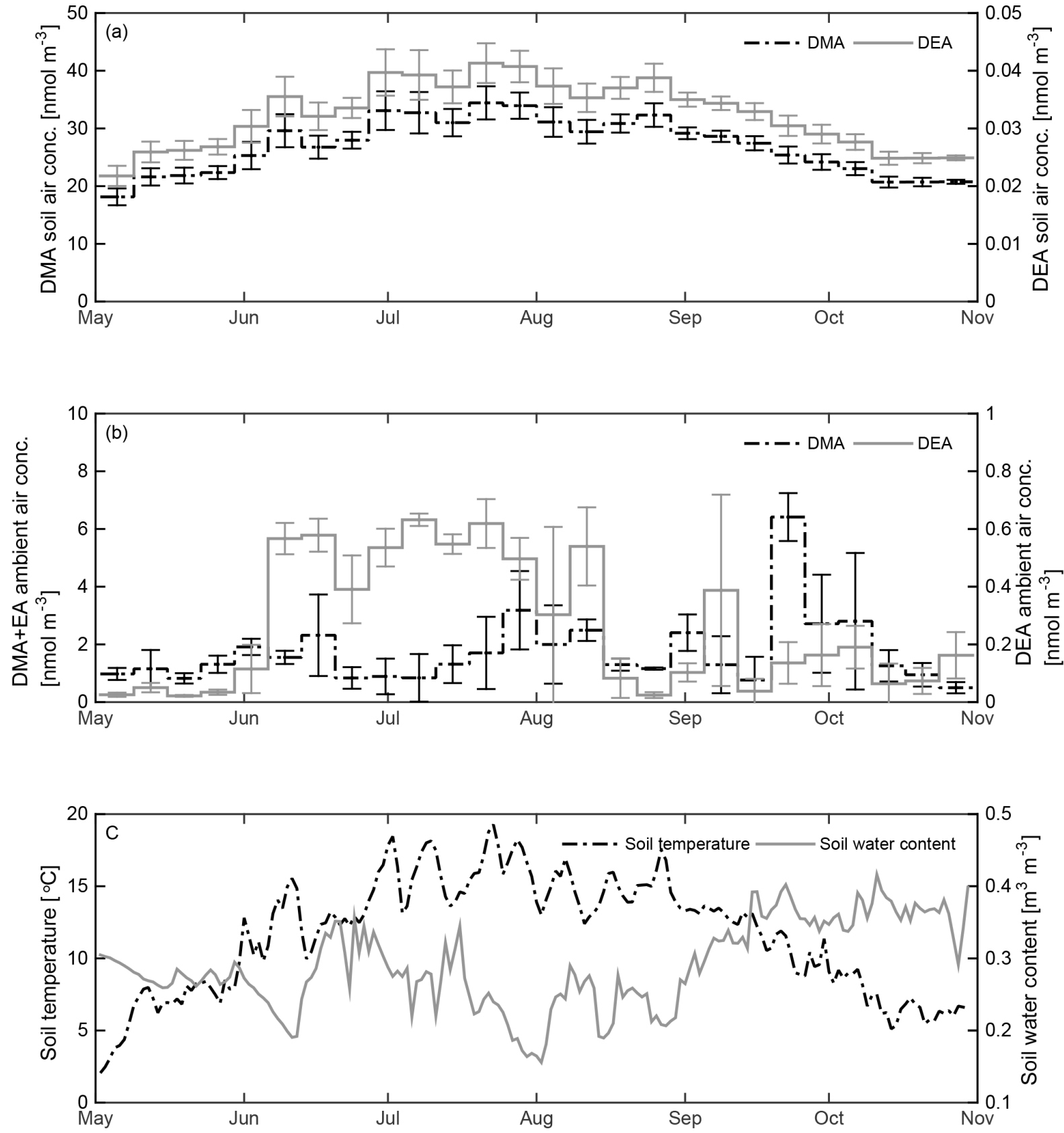

Figure 2. Estimated soil air concentrations of dimethylamine (DMA) and diethylamine (DEA) with their standard deviations at mean soil water $\mathrm{pH}$ of 5.3 (a); measured ambient air concentration of DMA + ethylamine and DEA (b) with their standard deviations redrawn from Kieloaho et al. (2013). In panel (c), measured soil temperature and soil water content from May 2011 to October 2011 are shown.

Table 2. Mean soil air concentrations and flux estimates for dimethylamine (DMA) and diethylamine (DEA) followed by their standard deviations in different soil $\mathrm{pH}$ values measured in lysimeter waters at $2 \mathrm{~cm}$ depth at SMEAR II station.

\begin{tabular}{lrrr|rrr}
\hline & \multicolumn{3}{c|}{ Dimethylamine (DMA) } & \multicolumn{3}{c}{ Diethylamine (DEA) } \\
\cline { 2 - 7 } Soil pH & 4.5 & 5.3 & 6.0 & 4.5 & 5.3 & 6.0 \\
\hline Soil air conc. $\left(\mathrm{nmol} \mathrm{m}^{-3}\right.$ ) & $0.68 \pm 0.13$ & $27 \pm 5.0$ & $680 \pm 130$ & $8.1 \times 10^{-4}$ & $0.03 \pm 0.01$ & $0.81 \pm 0.15$ \\
Flux/measured air conc. $\left(\mathrm{nmol} \mathrm{m}^{-2}\right.$ day $^{-1}$ ) & $-0.67 \pm 0.68$ & $170 \pm 51$ & $4500 \pm 1300$ & $-0.14 \pm 0.12$ & $-1.2 \pm 1.2$ & $2.7 \pm 1.0$ \\
\hline
\end{tabular}



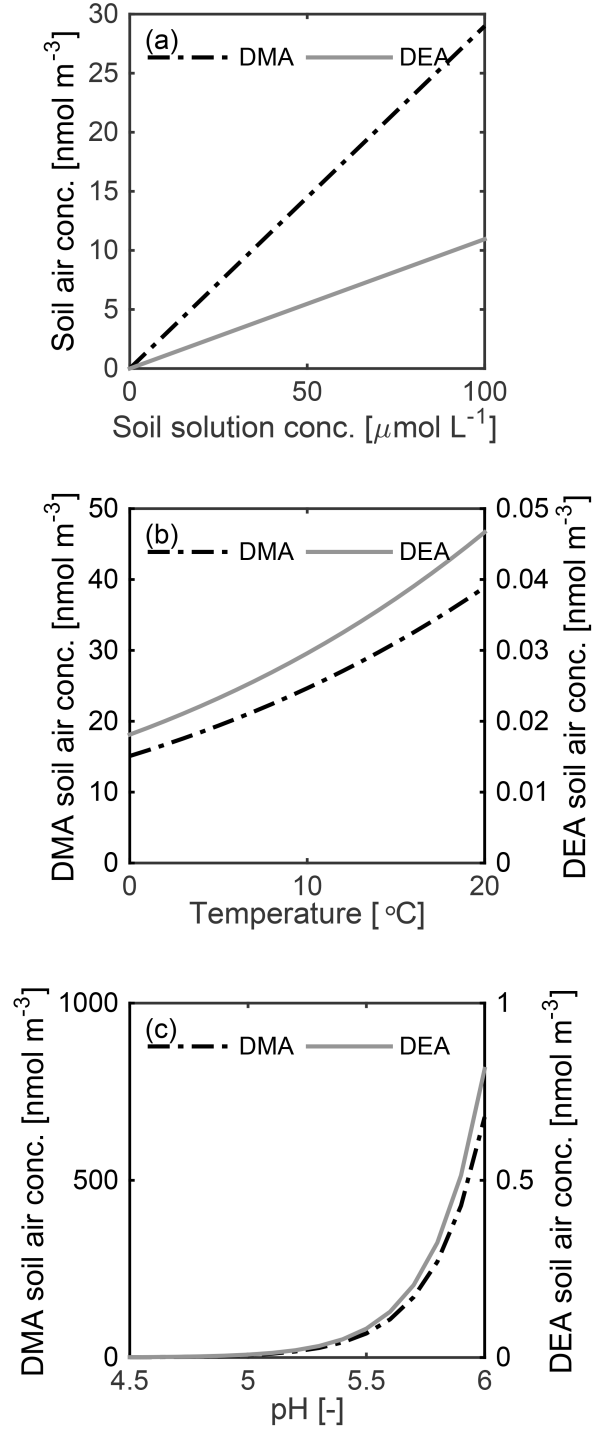

Figure 3. Effects of soil solution concentration (a), soil temperature (b), and soil solution $\mathrm{pH}$ (c) on estimated soil air concentrations of dimethylamine (DMA) and diethylamine (DEA).

A change of $10 \%$ in DEA soil solution concentrations lead to a change in turning point $\mathrm{pH}$ of \pm 0.06 . Decrease in $\mathrm{pH}$ decreased the available DMA and DEA concentrations and affected partitioning between soil water and soil air, but the proton concentration had no influence on the transport processes.

Soil temperature increase from 0 to $20^{\circ} \mathrm{C}$ increased DMA fluxes from 81 to $255 \mathrm{nmol} \mathrm{m}^{-2}$ day $^{-1}$ near-linear manner, and DEA fluxes from -1.1 to $1.3 \mathrm{nmol} \mathrm{m}^{-2} \mathrm{day}^{-1}$ (Fig. 6c) near-linearly. Fluxes decrease near-linearly with increasing soil water content (Fig. 6d). This is due to nonlinear increase of $r_{g}$ with increasing soil water content (Fig. S2). In assessed soil water content range DMA flux changed from
241 to $122 \mathrm{nmol} \mathrm{m}^{-2} \mathrm{day}^{-1}$ and DEA flux from -1.7 to $-0.84 \mathrm{nmol} \mathrm{m}^{-2}$ day $^{-1}$ (Fig. 6d).

The estimated soil-atmosphere fluxes are sensitive to the assumed depth of amine sources and sinks in the soil. Because of the dominating role of soil resistance, the absolute value of flux decrease with soil depth, and the sensitivity is strongest when soil depth is under $0.03 \mathrm{~m}$ (Fig. 6c) Increasing friction velocity decreases soil boundary-layer and aerodynamic resistances and modestly affect the flux estimates (Fig. 6f). The strongest impact occurs at friction velocity values smaller than $0.2 \mathrm{~m} \mathrm{~s}^{-1}$ and is mostly due to $r_{\mathrm{b}}$ (Fig. S2). It should be noted that the friction velocity may become an important factor affecting the flux estimates in calm conditions if the amine sources or sinks are located very close to the surface, causing $r_{g}$ and $r_{\mathrm{b}}$ to be of the same order of magnitude.

The flux estimates were modestly sensitive to assumed diurnal cycle of ambient air concentration. Assuming air-temperature-dependent diurnal cycle, the DMA flux was $170( \pm 61.8) \mathrm{nmol} \mathrm{m}^{-2}$ day $^{-1}$ and DEA flux was $-1.12( \pm 2.79) \mathrm{nmol} \mathrm{m}^{-2} \mathrm{day}^{-1}$. In the second scenario, which assumes the amine concentration behave as that of monoterpenes, the DMA flux was $169( \pm 55.8) \mathrm{nmol} \mathrm{m}^{-2} \mathrm{day}^{-1}$ and for DEA the flux was $-1.22( \pm 2.90) \mathrm{nmol} \mathrm{m}^{-2} \mathrm{day}^{-1}$.

\section{Discussion}

The results of this study shows that soil is an important reservoir of alkylamines, and our results suggest that this may be due to high amine concentrations in fungal hyphae in the boreal forest soil. Furthermore, we show in the flux estimation that these compounds can be released from the soil into the atmosphere under favorable environmental conditions. The source-sink behavior was dependent on soil conditions including temperature, soil water content, and $\mathrm{pH}$. Soil was shown to act as a source of DMA and a sink of DEA. The fact that both the DMA and DEA concentrations were much higher in the fungal hyphae and in fungal pure cultures as compared to the humus or mineral soil indicates that the fungal community may be the primary source of these alkylamines in boreal forest soils.

Both the concentrations of DMA and DEA in humus samples from the greenhouse experiment (Kieloaho et al., 2016) were lower than those of the fungal pure cultures (Table 1). The DMA concentrations were higher than DEA concentrations in the humus samples and in pure fungal cultures. Overall, the DEA concentration in the humus samples of the greenhouse experiment were lower than those measured from the field humus samples (Table 1).

In both sample types, field-collected hyphae and pure fungal cultures, DEA were found in the same range strongly supporting each other, and show that fungi are a reservoir of DEA. DEA concentrations found in the humus soil may 

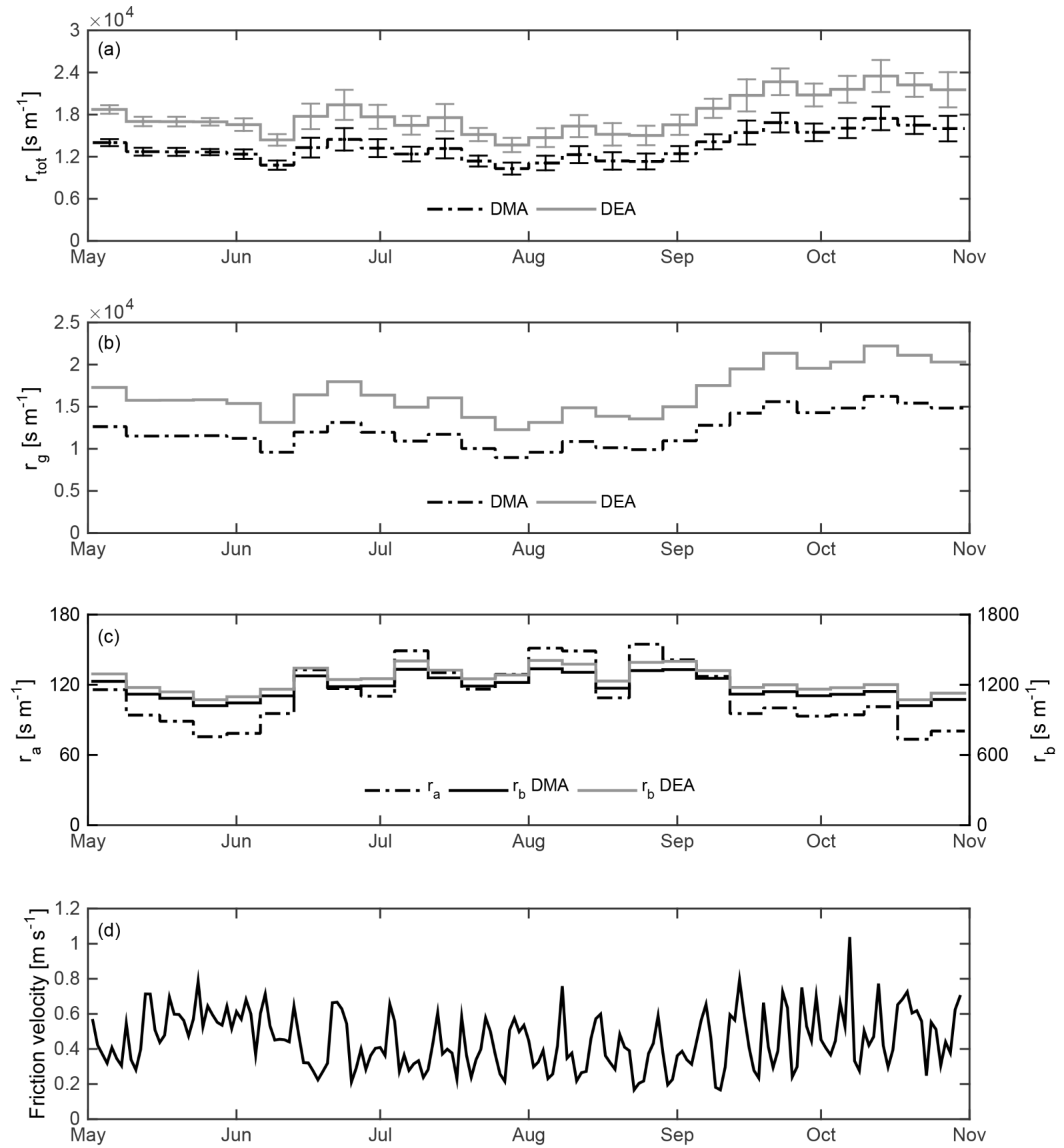

Figure 4. Total resistance $\left(r_{\text {tot }}, \mathrm{s} \mathrm{m}^{-1}\right)$ of dimethylamine (DMA) and diethylamine (DEA) and its components: soil resistance $\left(r_{g}\right.$, b) aerodynamic resistance $\left(r_{\mathrm{a}}, \mathrm{s} \mathrm{m}^{-1}, \mathbf{c}\right)$, and quasi-laminar resistance $\left(r_{\mathrm{b}}, \mathrm{s} \mathrm{m}^{-1}, \mathbf{b}\right)$. Soil resistance $\left(r_{g}, \mathrm{~s} \mathrm{~m}^{-1}\right)$ is calculated using $0.05 \mathrm{~m}$ soil depth. In panel (d) the daily mean of above-canopy friction velocity ( $\mathrm{m} \mathrm{s}^{-1}$ ) from May 2011 to October 2011 is shown. The error bars in panel (a) show $\pm 1 \mathrm{SD}$.

reflect concentrations found in fungal biomass and may be of fungal origin. In the pure fungal culture biomass, DMA concentrations were 50 times higher than those measured for DEA. DMA concentrations were also higher than DEA concentrations in the soil used in the greenhouse experiment. There is a possibility that degradation of sample compounds results in formation of the studied analytes during the sample preparation procedure. This, however, could not be assessed due to the absence of suitable reference materials, thus increasing the measurement uncertainty. Similarly, some of the studied amines could have degraded into smaller compounds 

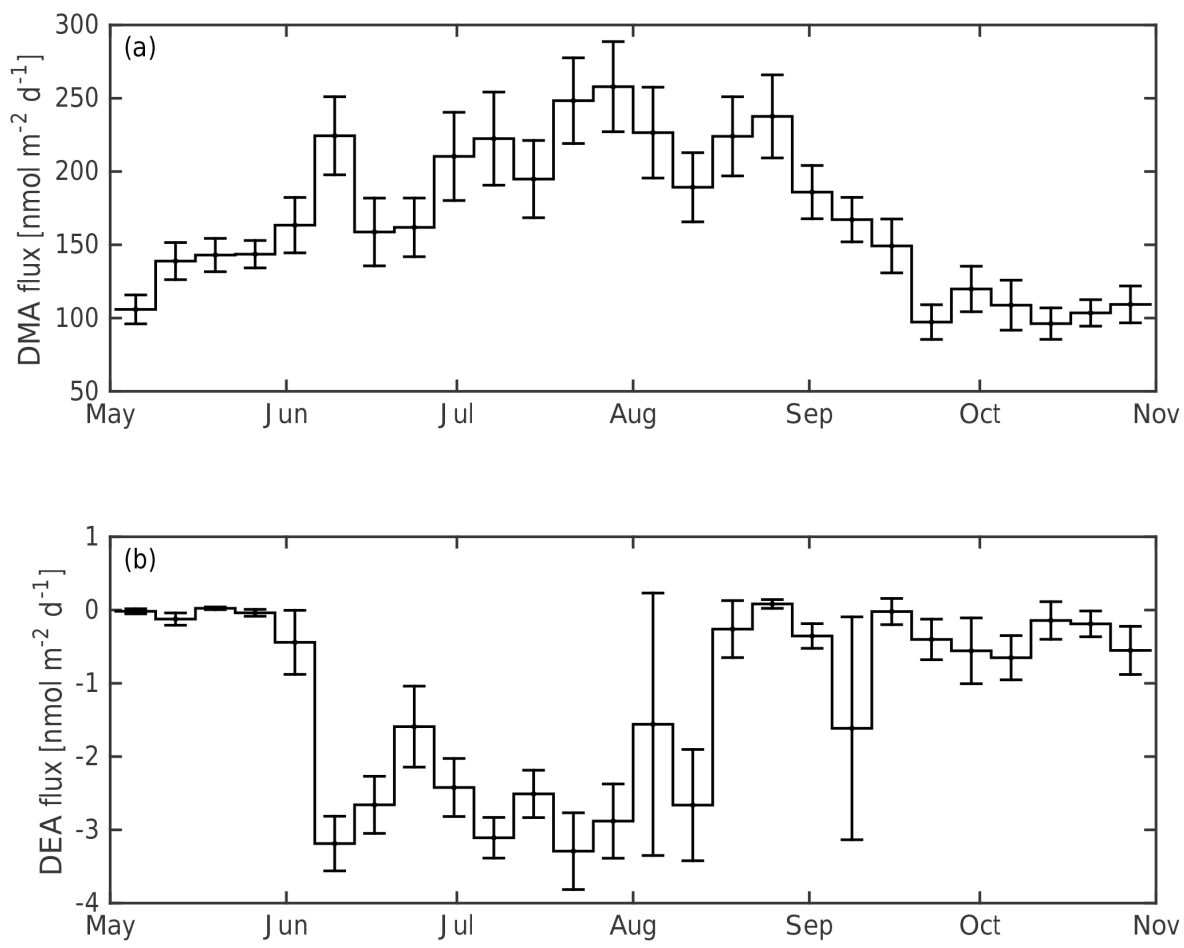

Figure 5. Weekly averages of estimated fluxes of dimethylamine (DMA, a) and diethylamine (DEA, b) and their standard deviations from May 2011 to October 2011. In emission estimation constant soil solution pH 5.3, average soil depth of $0.05 \mathrm{~m}$, and constant soil solution concentrations of DMA and DEA $\left(92.3\right.$ and $0.296 \mu \mathrm{mol} \mathrm{L}^{-1}$, respectively) were used.

and hence not be detected in our analysis, leading to underestimation of the concentrations of the studied compounds.

Fungal sporocarps were shown to contain of monomethylamine, dimethylamine, and trimethylamine (Sintermann and Neftel, 2015). However, these measurements were based on fungal sporocarps and not on fungal hyphae, which is the only one form of fungi present in forest soils. Fungal sporocarps occur seasonally and sporadically mainly in autumn, whereas fungal hyphae are found throughout the year in forest soil (Santalahti et al., 2016). Therefore, the sporocarp data do not necessarily reflect the most important fungal contribution as a source of alkylamines in boreal forest ecosystems.

The fungal community of boreal forest soil undergoes seasonal variation. Santalahti et al. (2016) observed a clear soil fungal community shift in which the ectomycorrhizal fungi seem to disappear in late autumn while saprotrophic community dominates in the winter. In this study we show that ectomycorrhizal fungi contain high quantities of DMA and DEA, which could be released into the soil solution and subsequently to the atmosphere during their disappearance in late autumn. In boreal Norway spruce forest in Sweden, Wallander et al. (2001) estimated that humus contains 700$900 \mathrm{~kg} \mathrm{ha}^{-1}$ ectomycorrhizal hyphae, which is equal to the amount of fine roots found in humus.

The estimated soil air concentrations correlated positively with the measured ambient air concentrations of DEA but not with DMA. Kieloaho et al. (2011) found a strong correlation between ambient air concentration of DEA and ambient air monoterpene concentration and suggested that the source of DEA might be in vegetation, as has been suggested for monoterpenes (Hakola et al., 2006). In this study, the estimated soil air concentrations of DEA were smaller than the measured ambient air concentrations, which suggests that the soil is not necessarily a source of atmospheric DEA. The soil air concentrations are based on limited data of soil solution concentrations, and the results serve as the first estimates for both soil air concentrations and soil fluxes for DMA and DEA. DMA and DEA were assumed to have similar exchange processes with $\mathrm{NH}_{3}$, having both sink and source behavior between the soil and the atmosphere

At the end of September and in October, the flux estimates of DMA and DEA did not explain the elevated atmospheric concentrations of DMA and DEA (Fig. 2b). This missing autumnal peak in the fluxes might be due to a rapid change in soil DMA concentration, which could not be taken into account in the soil air concentration estimates due to the lack of continuous soil solution concentration measurements. During the autumn (from September to October), litterfall provides an input of fresh decomposable material into the soil, which also has an immediate effect on soil nitrogen concentrations due to the nitrogen-rich leachate from the needle litter (Pihlatie et al., 2007; Starr et al., 2014). It was also re- 

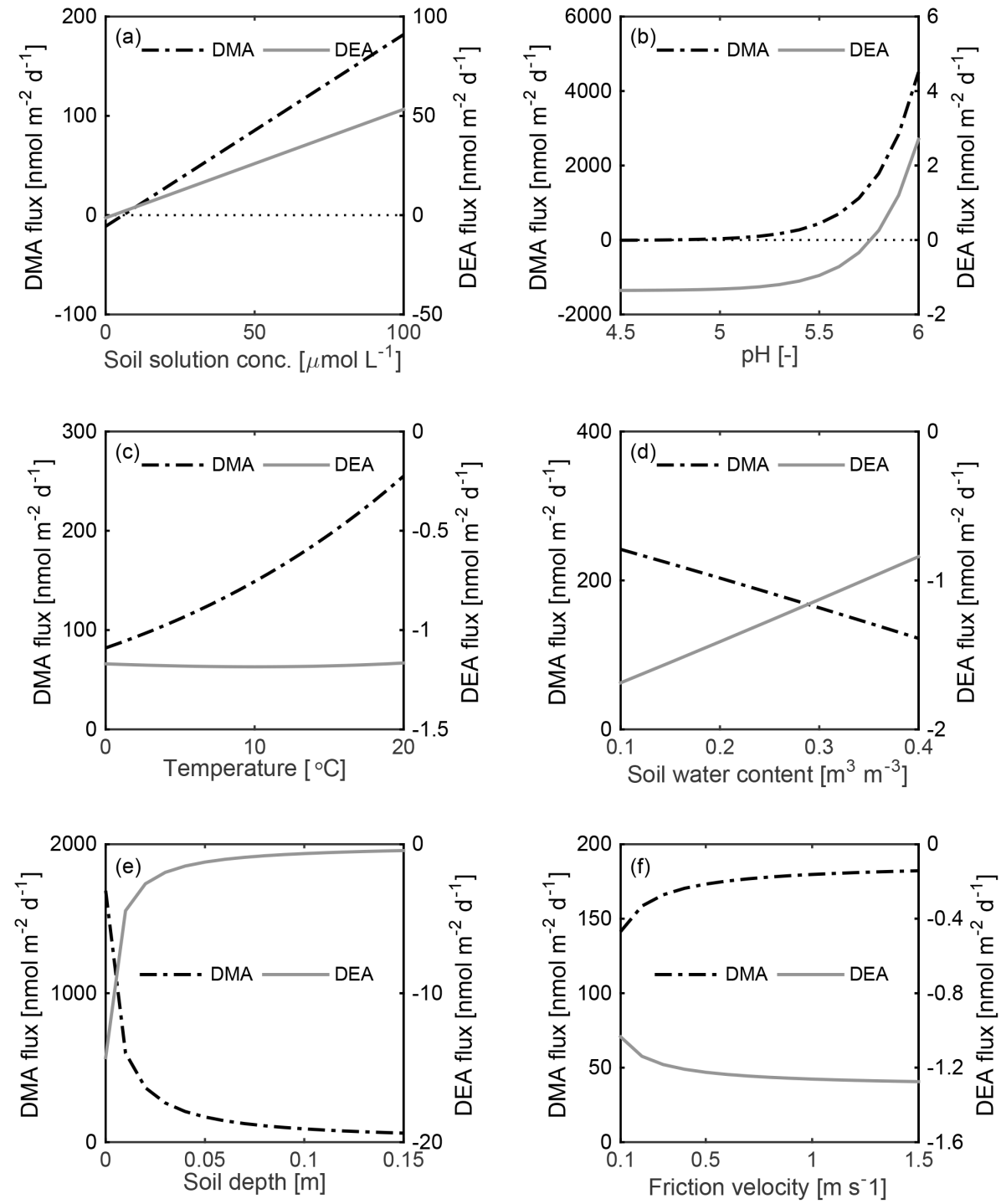

Figure 6. Effect of soil solution concentration (a), soil pH (b), temperature (c), soil water content (d), organic soil depth (e), and abovecanopy friction velocity (f) on soil flux estimates of dimethylamine (DMA) and diethylamine (DEA).

cently shown that a common ectomycorrhizal fungal genus Piloderma sp., which also contained the highest quantities of alkylamines in our study, has a clear seasonal pattern, and it seems to disappear from the soil in late autumn (Heinonsalo et al., 2015). Piloderma sp. was shown to be active in protease production; protease is an enzyme that facilitates the decomposition of proteins, possibly due to the protease activity. Piloderma sp. was also found to be able to obtain $\mathrm{N}$ from organic sources and deliver proteinaceous $\mathrm{N}$ to the host plant Scots pine. This involvement of ectomycorrhizal fungi in soil organic N cycling may make them "nitrogen hotspots" that release also alkylamines into soil solution after their death (Heinonsalo et al., 2015).

Flux estimates were found to be sensitive to soil temperature, soil $\mathrm{pH}$ and soil water content, and soil resistance had a major effect on transport, while aerodynamic and quasilaminar resistances had only minor effects on the fluxes of DMA and DEA. We found that DMA and DEA flux estimates were especially sensitive to change in soil $\mathrm{pH}$. Flux estimates were calculated based on three $\mathrm{pH}$ values, mean $\mathrm{pH}$ (5.3) and 10th and 90th percentiles (4.5 and 6.0, respectively). The $\mathrm{pH}$, in which the mean flux estimate is zero, is a compensation point with respect to soil $\mathrm{pH}$. Below the compensation point $\mathrm{pH}$, direction of alkylamine flux is into the soil and soil is a sink of alkylamines. The compensation point $\mathrm{pH}$ occurred for DMA at $\mathrm{pH} 4.7$, which is lower than the mean measured $\mathrm{pH}$ from suction lysimeters, indicating that boreal forest soil can act as a DMA source at least occasionally. In contrary, for DEA the compensation point with respect to $\mathrm{pH}$ was 5.7 , which is close to the 90th percentile 

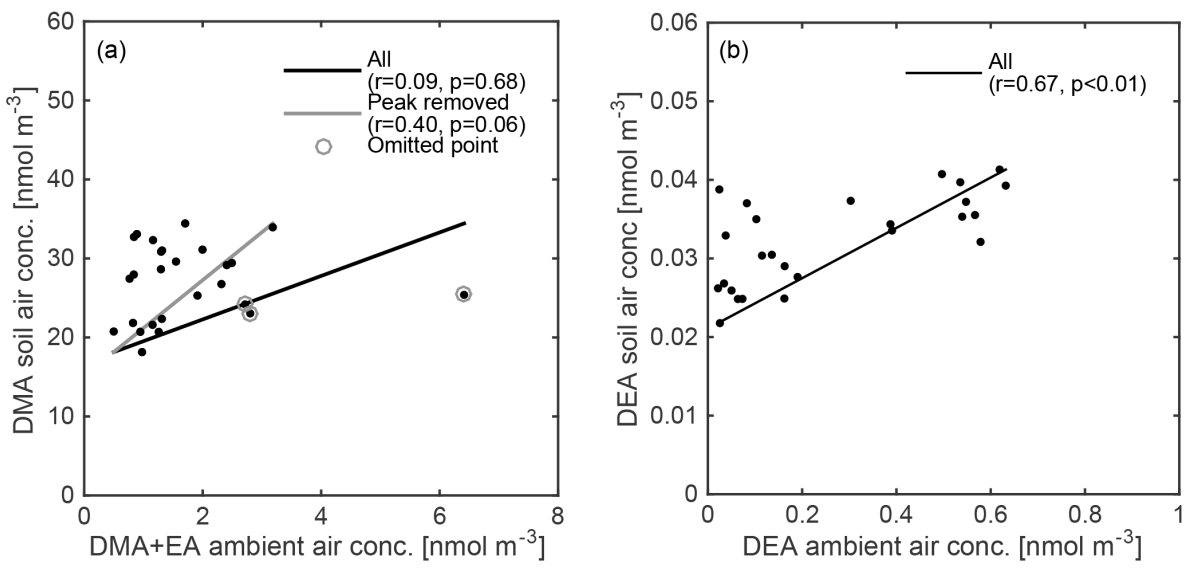

Figure 7. The comparison of measured ambient air concentrations and estimated soil air concentrations of dimethylamine (DMA) and diethylamine (DEA) (panels a and $\mathbf{b}$, respectively) with linear least square fits. In the case of DMA, three data points from autumn have been omitted (see Sect. 3.3), while the least square fits without removed points are shown for comparison.

(pH 6.0), indicating that soil is a sink of DEA. The compensation point $\mathrm{pH}$ is dependent on soil solution concentration of the amine. Hence, it is clear that even a slight change in soil $\mathrm{pH}$ or alkylamine concentration in soil solution could determine the capability of boreal forest soil to act as a source or a sink of alkylamines. The diurnal cycles of ambient air concentrations of the studied amines are still currently unknown. By introducing artificial diurnal cycles as observed for trimethylamine or $\mathrm{NH}_{3}$ (You et al., 2014) and monoterpenes (Hakola et al., 2012), it was found that it the diurnal cycles are not likely to have major effect on estimated DMA flux. However, the unknown diurnal cycle of ambient DEA concentration may significantly contribute to the uncertainty and even to the direction of the estimated soil-atmosphere DEA flux.

Current understanding of the atmospheric alkylamine sources is mainly from rural areas where the alkylamine emissions are related to agricultural activities (Schade and Crutzen, 1995; Kuhn et al., 2011). Schade and Crutzen (1995) have suggested using a constant ratio between TMA and $\mathrm{NH}_{3}$ in total agricultural emissions as a proxy for agricultural alkylamine emissions. TMA emissions were $0.3 \%$ from $\mathrm{NH}_{3}$ emissions from livestock farming and it can be partly explained by the same formation pathway of alkylamines and $\mathrm{NH}_{3}$ (Kim et al., 2001; Rappert and Müller, 2005). The proxy was, however, revised by Kuhn et al. (2011), who suggested that TMA emissions are $0.1 \%$ from $\mathrm{NH}_{3}$ emissions for both livestock farming and vegetation. Mineral soils have been found to be a sink for atmospheric $\mathrm{NH}_{3}$ while litter of organic layer may act as a source of $\mathrm{NH}_{3}$ (Neftel et al., 1998; Schjoerring et al., 1998; Nemitz et al., 2000).

It has been proposed that $\mathrm{NH}_{4}^{+}$is adsorbed onto soil particles in mineral soil and hence is not available for gas exchange between soil solution and gas phase (Neftel et al.,
1998). In contrast, peat soil and litter layer have been shown to be periodically sources of atmospheric $\mathrm{NH}_{3}$ in the laboratory (Schjoerring et al., 1998) and in the field (Nemitz et al., 2000). Previously Hansen et al. (2013) observed $\mathrm{NH}_{3}$ emissions after a litterfall in a deciduous forest in Denmark, indicating that changes in nitrogen inputs may influence $\mathrm{NH}_{3}$ dynamics. The ambient air measurements of $\mathrm{NH}_{3}$ in boreal forest air indicate that $\mathrm{NH}_{3}$ may be emitted from the ecosystem in the summer and in autumn as the concentrations of $\mathrm{NH}_{3}$ in boreal forest air peak during this period and remain lower in the spring and in winter months (Makkonen et al., 2014). To our knowledge, the only measured alkylamine fluxes from forested areas are TMA fluxes measured above a Douglas fir forest from June to July in Netherlands (Copeland et al., 2014). The mean TMA flux during this 1-month measurement period was around zero, showing occasional uptake and emission from -192 to $192 \mu \mathrm{mol} \mathrm{m}^{-2}$ day $^{-1}$, which is 1 order of magnitude higher than the DMA flux estimate $\left(170 \mathrm{nmol} \mathrm{m}^{-2}\right.$ day $\left.^{-1}\right)$ in this study.

The mean DMA flux of $170 \mathrm{nmol} \mathrm{m}^{-2}$ day $^{-1}$ is approximately $9 \mathrm{~g} \mathrm{ha}^{-1} \mathrm{yr}^{-1}$ and the annual flux is slightly higher than that of nitrous oxide $\left(\mathrm{N}_{2} \mathrm{O}, 3 \mathrm{~g} \mathrm{ha}^{-1} \mathrm{yr}^{-1}\right)$ measured from the studied forest (Pihlatie et al, 2007; Korhonen et al., 2013). It is likely that soil fluxes of reduced $\mathrm{N}$ are higher than those of oxidized forms (e.g., $\mathrm{HONO}$ and $\mathrm{N}_{2} \mathrm{O}$ ) due to higher dissolved organic nitrogen and $\mathrm{NH}_{4}^{+}$concentrations in soil solution (Korhonen et al., 2013). Unlike in agricultural soils, Korhonen et al. (2013) showed that in the studied forest $98.9 \%$ of the extractable $\mathrm{N}$ is in the form of organic $\mathrm{N}\left(26.8 \mathrm{~kg} \mathrm{Nha}^{-1}\right)$ and most of the mineral nitrogen is in the form of ammonium $\left(0.31 \mathrm{~kg} \mathrm{Nha}^{-1}\right)$. In the studied forest site O-horizon contained $710 \mathrm{~kg} \mathrm{Nha}^{-1}$ and it is approximately $34 \%$ of total $\mathrm{N}$ pool in the forest being the highest nitrogen pool in the studied forest ecosystem (Korhonen et al., 2013). Mycorrhizal fungi are capable of degrading and uti- 
lizing organic $\mathrm{N}$ compounds in soil as nutrient source (Talbot and Treseder, 2010). Hence, we suggest that soil fungi could also release amines into the soil solution as we demonstrated that they contain high quantities of amines.

At the moment, ambient air concentration measurements of alkylamines from remote forested areas are scarce. Recently, there have been several efforts to measure ambient air amine concentrations using online ion chromatograph connected with quadruple mass spectrometer (Hemmilä et al., 2014) and CI-API-ToF (Kulmala et al., 2013; Sipilä et al., 2015). However, they are so far only the first steps in characterizing the amine concentrations and no continuous datasets are yet available. Flux estimation presented in this study was based on ambient air concentration measurements conducted by Kieloaho et al. (2013). More recently, Sipilä et al. (2015) suggested that measured maximum ambient air concentrations of DMA is $0.06 \mathrm{nmol} \mathrm{m}^{-3}$ in spring and early summer (from May to June 2013), but due to problems in measurement system and lack of calibration they advised viewing these numbers with caution. This implies that if the forest soil is a reservoir of DMA, the real fluxes may be higher than those presented in this study if the atmospheric concentrations of DMA are as low as those presented by Sipilä et al. (2015). However, Hemmilä et al. (2014) reported preliminary results of ambient air concentrations of DMA and DEA in summertime (June-July) at Hyytiälä Scots pine forest to be 0.4 and $0.08 \mathrm{nmol} \mathrm{m}^{-3}$ for DMA and DEA, respectively. These results from June to July indicate that the ambient air measurements by Kieloaho et al. (2013) are in the correct range. The week-long sampling time of ambient air DMA+EA and DEA concentrations (Kieloaho et al., 2013) coupled with the mixing of air, atmospheric sink processes, and deposition of alkylamines onto the surfaces affect the measured concentrations and diminish the relationship between source and ambient air concentrations. Hence, the flux estimates for DMA and DEA in this study can be used as the first attempts to estimate potential soil-atmosphere exchange in forests.

The concentration of ammonium in soil water is expected to change with substrate availability, environmental conditions, microbial activity, and due to assimilation of nutrients by either soil microbes or vegetation (Pajuste and Frey, 2003). Assuming that DMA and DEA share similar formation and consumption processes with ammonium in the soil, as suggested by Kim et al. (2001) and Rappert and Müller (2005), DMA and DEA concentrations in boreal forest soil may have two maxima during a year, in early spring and in late autumn (Pajuste and Frey, 2003). The two maxima are due to the combination of supply and demand of ammonium from temperature-dependent ammonium-releasing soil processes (decomposition and mineralization), and plant and microbial uptake rates. In the spring, the decomposition produces ammonium while the plant uptake still remains rather low, whereas towards the late summer plant uptake exceeds the mineralization rate, leading to minimum concentrations in the soil. In late autumn, plant uptake decreases faster than the mineralization rate, leading to a slight increase in ammonium concentration in soil (Pajuste and Frey, 2003).

\section{Conclusion}

We have shown that boreal forest soil and fungal hyphae in the soil contain alkylamines, which can be released to the atmosphere in favorable conditions. We hypothesize that the soil-atmosphere exchange of the studied alkylamines (DMA and DEA) can be estimated based on soil temperature, soil water content, and especially soil $\mathrm{pH}$. Soil was shown to be a source of DMA and a sink of DEA at typical soil pH(5.3) levels. The flux estimation method presented here is a first attempt to quantify the sources and sinks of alkylamines and other similar compounds that are difficult to measure directly in forest ecosystems. In boreal forest soil, fungal hyphae seem to form a large pool of low-molecular-weight amines like DMA and DEA. Therefore, we propose that fungi are the origin of alkylamines in boreal forest soils. The functional role of boreal forest soil as a source of low-molecular-weight amines, as well as their potential emissions, needs to be further investigated in relation to air chemistry and atmospheric aerosol formation processes. In parallel, more measurements on atmospheric and soil air amine concentrations are needed to confirm the flux estimates provided in this study.

Data availability. The soil and meteorological data used in this article are freely available at https://avaa.tdata.fi/web/smart (AVAA, 2017), and the ambient air concentrations of alkylamines used in this article are freely available at http://urn.fi/urn:nbn:fi: csc-ida-2x201703012015017556884s (Kieloaho, 2017).

\section{The Supplement related to this article is available online at doi:10.5194/bg-14-1075-2017-supplement.}

Competing interests. The authors declare that they have no conflict of interest.

Acknowledgements. The authors greatly acknowledge Tiia Grönholm for the help in finalizing this work. This work was supported by Academy of Finland Centre of Excellence Programme (project number 1118615), Academy of Finland Research grants (263858, 259217, 292699, and 296116), and the CRAICC and DEFROST Nordic Centres of Excellences.

Edited by: I. Trebs

Reviewed by: A. Neftel and one anonymous referee 


\section{References}

Almeida, J., Schobesberger, S., Kürten, A., Ortega, I. K., Kupiainen-Määttä, O., Praplan, A. P., Adamov, A., Amorim, A., Bianchi, F., Breitenlechner, M., David, A., Dommen, J., Donahue, N.M., Downard, A., Dunne, E., Duplissy, J., Ehrhart, S., Flagan, R. C., Franchin, A., Guida, R., Hakala, J., Hansel, A., Heinritzi, M., Henschel, H., Jokinen, T., Junninen, H., Kajos, M., Kangasluoma, J., Keskinen, H., Kupc, A., Kurtén, T., Kvashin, A. N., Laaksonen, A., Lehtipalo, K., Leiminger, M., Leppä, J., Loukonen, V., Makhmutov, V., Mathot, S., McGrath, M. J., Nieminen, T., Olenius, T., Onnela, A., Petäjä, T., Riccobono, F., Riipinen, I., Rissanen, M., Rondo, L., Ruuskanen, T., Santos, F. D., Sarnela, N., Schallhart, S., Schnitzhofer, R., Seinfeld, J. H., Simon, M., Sipil, M., Stozhkov, Y., Stratmann, F., Tomé, A., Tröstl, J., Tsagkogeorgas, G., Vaattovaara, P., Viisanen, Y., Virtanen, A., Vrtala, A., Wagner, P. E., Weingartner, E., Wex, H., Williamson, C., Wimmer, D., Ye, P., Yli-Juuti, T., Carslaw, K. S., Kulmala, M., Curtius, J., Baltensperger, U., Worsnop, D. R., Vehkamäki, H., and Kirkby, J.: Molecular understanding of sulphuric acid-amine particle nucleation in the atmosphere, Nature, 502, 359-363, 2013.

Angelino, S., Suess, D. T., and Prather, K. A.: Formation of aerosol particles from reactions of secondary and tertiary alkylamine: characterization by aerosol time-of-flight mass spectrometry, Environ. Sci. Technol., 35, 3130-3138, 2001.

AVAA: Soil and meteorological data https://avaa.tdata.fi/web/smart, last access: 2 March 2017.

Bäck, J., Aaltonen, H., Hellén, H., Kajos, M. K., Patokoski, J., Taipale, R., Pumpanen, J., and Heinonsalo, J.: Variable emissions of microbial volatile organic compounds (MVOCs) from root-associated fungi isolated from Scots pine, Atmos. Environ., 44, 3651-3659, 2010.

Baldocchi, D.: A multi-layer model for estimating sulfur-dioxide deposition to a deciduous oak forest canopy, Atmos. Environ., 22, 869-884, 1988.

Copeland, N., Cape, J. N., and Heal, R. H.: Volatile organic compound speciation above and within a Douglas Fir forest, Atmos. Environ., 94, 86-95, 2014.

Farquhar, G. D., Firth, P. M., Wetselaar, R., and Weir, B.: On the gaseous exchange of ammonia between leaves and the environment: determination of the ammonia compensation point, Plant Physiol., 66, 710-714, 1980.

Ge, X., Wexler, A. S., and Clegg, S. L.: Atmospheric amines - Part I, A review, Atmos. Environ., 45, 524-546, 2011.

Glinski, J. and Stepniewski, W.: Soil aeration and its role for plants, CRC Press, Boca Raton, FL, USA, 1985.

Hakola, H., Tarvainen, V., Bäck, J., Ranta, H., Bonn, B., Rinne, J., and Kulmala, M.: Seasonal variation of mono- and sesquiterpene emission rates of Scots pine, Biogeosciences, 3, 93-101, doi:10.5194/bg-3-93-2006, 2006.

Hakola, H., Hellén, H., Hemmilä, M., Rinne, J., and Kulmala, M.: In situ measurements of volatile organic compounds in a boreal forest, Atmos. Chem. Phys., 12, 11665-11678, doi:10.5194/acp12-11665-2012, 2012.

Hansen, K., Sørensen, L. L., Hertel, O., Geels, C., Skjøth, C. A., Jensen, B., and Boegh, E.: Ammonia emissions from deciduous forest after leaf fall, Biogeosciences, 10, 4577-4589, doi:10.5194/bg-10-4577-2013, 2013.
Hari, P. and Kulmala, M.: Station for measuring ecosystematmosphere relations (SMEAR II), Boreal Environ. Res., 10, 315-322, 2005.

Heinonsalo, J., Sun, H., Santalahti, M., Backlund, K., Hari, P., and Pumpanen, J.: Evidence on the ability of mycorrhizal genus $\mathrm{Pi}$ loderma to use organic nitrogen and deliver it to Scots pine, Plos One, 10, e0131561, doi:10.1371/journal.pone.0131561, 2015.

Hellén, H., Kieloaho, A.-J., and Hakola, H.: Gas-phase alkyl amines in urban air; comparison with a boreal forest site and importance for local atmospheric chemistry, Atmos. Environ., 94, 192-197, 2014.

Hemmilä, M., Hellén, H., Makkonen, U., and Hakola, H.: Developing method for ambient air amine measurements, FAAR Report Series part A: Proceedings of "the Center of Excellence in Atmospheric Science (CoE Atm) - From Molecular and Biological Processes to the Global Climate", Annual Meeting 2014, edited by: Kulmala, M., Lintunen, A., and Kontkanen, J., 300303, 2014.

Hicks, B. B., Baldocchi, D. D., Meyers, T. P., Hosker Jr., R. P., and Matt, D. R.: A preliminary multiple resistance routine for deriving dry deposition velocities from measured quantities, Water Air Soil Poll., 36, 311-330, 1987.

Ilvesniemi, H., Levula, J., Ojansuu, R., Kolari, P., Kulmala, L., Pumpanen, J., Launiainen, S., Vesala, T., and Nikinmaa, E.: Long-term measurements of the carbon balance of a boreal Scots pine dominated forest ecosystem, Boreal Environm. Res., 14, 731-753, 2009.

Kerminen, V.-M., Petäjä, T., Manninen, H. E., Paasonen, P., Nieminen, T., Sipilä, M., Junninen, H., Ehn, M., Gagné, S., Laakso, L., Riipinen, I., Vehkamäki, H., Kurten, T., Ortega, I. K., Dal Maso, M., Brus, D., Hyvärinen, A., Lihavainen, H., Leppä, J., Lehtinen, K. E. J., Mirme, A., Mirme, S., Hõrrak, U., Berndt, T., Stratmann, F., Birmili, W., Wiedensohler, A., Metzger, A., Dommen, J., Baltensperger, U., Kiendler-Scharr, A., Mentel, T. F., Wildt, J., Winkler, P. M., Wagner, P. E., Petzold, A., Minikin, A., Plass-Dülmer, C., Pöschl, U., Laaksonen, A., and Kulmala, M.: Atmospheric nucleation: highlights of the EUCAARI project and future directions, Atmos. Chem. Phys., 10, 10829-10848, doi:10.5194/acp-10-10829-2010, 2010.

Kieloaho, A.-J., Hellén, H., Hakola, H., Manninen, H.E., Nieminen, T., Kulmala, M., and Pihlatie, M.: Gas-phase alkylamines in a boreal Scots pine forest air, Atmos. Environ., 80, 369-377, 2011.

Kieloaho, A.-J., Hellén, H., Hakola, H., Manninen, H. E., Nieminen, T., Kulmala, M., and Pihlatie, M.: Gas-phase alkylamine in a boreal Scots pine forest air, Atmos. Environ., 80, 369-377, 2013.

Kieloaho, A.-J., Pihlatie, M., Dominguez Carrasco, M., Kanerva, S., Parshintsev, J., Riekkola, M.-L., Pumpanen, J., and Heinonsalo, J.: Stimulation of soil organic nitrogen pool: The effect of plant and soil organic matter degrading enzymes, Soil Biol. Biochem., 96, 97-106, 2016.

Kieloaho, A.-J.: Ambient air concentrations of alkylamines in boreal Scots pine forest, available at: http://urn.fi/urn:nbn: fi:csc-ida-2x201703012015017556884s, last access: 2 March 2017.

Kim S.-G., Bae, H.-S., and Lee, S.-T.: A novel denitrifying bacterial isolated that degrades trimethylamine both aerobically and anaerobically via two different pathways, Arch. Microbiol., 176, 271-277, 2001. 
Korhonen, J. F. J., Pihlatie, M., Pumpanen, J., Aaltonen, H., Hari, P., Levula, J., Kieloaho, A.-J., Nikinmaa, E., Vesala, T., and Ilvesniemi, H.: Nitrogen balance of a boreal Scots pine forest, Biogeosciences, 10, 1083-1095, doi:10.5194/bg-10-1083-2013, 2013.

Kuhn, U., Sintermann, J., Spirig, C., Jocher, M., Ammann, C., and Neftel, A.: Basic biogenic aerosol precursors: agricultural source attribution of volatile amines revised, Geophys. Res. Lett., 38, L16811, doi:10.1029/2011GL047958, 2011.

Kulmala, M., Toivonen, A., Makela, J. M., and Laaksonen, A.: Analysis of the growth of nucleation mode particles observed in boreal forest, Tellus B, 50, 449-462, 1998.

Kurtén, T., Loukonen, V., Vehkamäki, H., and Kulmala, M.: Amines are likely to enhance neutral and ion-induced sulfuric acid-water nucleation in the atmosphere more effectively than ammonia, Atmos. Chem. Phys., 8, 4095-4103, doi:10.5194/acp-8-4095-2008, 2008.

Launiainen, S., Vesala, T., Mölder, M., Mammarella, I., Smolander, S., Rannik, Ü., Kolari, P., Hari, P., Lindroth, A., and Katul, G. G.: Vertical variability and effect of stability on turbulence characteristics down to the floor of a pine forest, Tellus B, 59, 919-936, 2007.

Launiainen, S., Katul, G. G., Grönholm, T., and Vesala, T.: Partiotining ozone fluxes between canopy and forest floor by measurements and a multi-layer model, Agr. Forest Meteorol., 173, 85-99, 2013.

Launiainen, S., Katul, G. G., Lauren, A., and Kolari, P.: Coupling boreal forest $\mathrm{CO}_{2}, \mathrm{H}_{2} \mathrm{O}$ and energy flows by a vertically structured forest canopy - soil model with separate bryophyte layer, Ecol. Model., 312, 385-405, 2015.

Linstrom, P. J. and Mallard, W. G.: NIST Chemistry WebBook, NIST Standard Reference Database Number 69, National Institute of Standards and Technology, Graithersburg, MD 20899, USA, available at: http://webbook.nist.gov (last access: 30 June 2016), 2014.

Mäkelä, J. M., Yli-koivisto, S., Hiltunen, V., Seidl, W., Swietlicki, E., Teinilä, K., Sillanpää, M., Koponen, I. K., Paatero, J., Rosman, K., and Hämeri, K.: Chemical composition of aerosol during particle formation events in boreal forest, Tellus B, 53, 380393, 2001

Makkonen, U., Virkkula, A., Hellén, H., Hemmilä, M., Sund, J., Äijälä, M., Ehn, M., Junninen, H., Keronen, P., Petäjä, T., Worsnop, D. R., Kulmala M., and Hakola, H.: Semi-continuos gas and inorganic aerosol measurements at a boreal forest site: seasonal and diurnal cycles of $\mathrm{NH}_{3}, \mathrm{HONO}$ and $\mathrm{HNO}_{3}$, Boreal Environ. Res., 19, 311-328, 2014.

Montes, F., Rotz, C. A., and Chaoui, H.: Process modeling of ammonia volatalization from ammonium solution and manure surfaces: a review with recommended models, T. ASABE, 52, 1707-1719, 2009.

Neftel, A., Blatter, A., Gut, A., Högger, D., Meixner, F., Ammann, C., and Nathaus, F. J.: $\mathrm{NH}_{3}$ soil and soil surface gas measurements in a triticale wheat field, Atmos. Environ., 32, 499-505, 1998.

Nemitz, E., Sutton, M. A., Gut, A., San José, R., Husted S., and Schjoerring, J. K.: Sources and sinks of ammonia within an oilseed rape canopy, Agr. Forest Meteorol., 105, 385-404, 2000.

Nemitz, E., Milford, C., and Sutton M. A.: A two-layer canopy compensation point model for describing bi-directional biosphere- atmosphere exchange of ammonia, Q. J. Roy. Meteor. Soc., 127, 815-833, 2001.

Pajuste, K. and Frey, J.: Nitrogen mineralization in podzol soils under boreal Scots pine and Norway spruce stands, Plant Soil, 257, 237-247, 2003.

Pihlatie, M., Pumpanen, J., Rinne, J., Ilvesniemi, H., Simojoki, A., Hari, P., and Vesala, T.: Gas concentration driven fluxes of nitrous oxide and carbon dioxide in boreal forest soil, Tellus B, 59, 458469, 2007.

Rappert, S. and Müller, R.: Microbial degradation of selected odorous substances, Waste Manage., 25, 940-954, 2005.

Riipinen, I., Yli-Juuti, T., Pierce, J. P., Petäjä, T., Worsnop, D. R., Kulmala, M., and Donahue, N. M.: The contribution of organics to atmospheric nanoparticle growth, Nat. Geosci., 5, 453-458, 2012.

Rinne, J., Markkanen, T., Ruuskanen, T. M., Petäjä, T., Keronen, P., Tang, M. J., Crowley, J. N., Rannik, Ü., and Vesala, T.: Effect of chemical degradation on fluxes of reactive compounds - a study with a stochastic Lagrangian transport model, Atmos. Chem. Phys., 12, 4843-4854, doi:10.5194/acp-12-4843-2012, 2012.

Ruiz-Jiminez, J., Hautala, S. S., Parshintsev, J., Laitinen, T., Hartonen, K., Petaja, T., Kulmala, M., and Riekkola, M.-L.: Aliphatic and aromatic amines in atmospheric aerosol particles: Comparison of three different techniques in liquid chromatographymass spectrometry and method development, Talanta, 97, 55-62, 2012.

Santalahti, M., Sun, H., Jumpponen, A., Pennanen, T., and Heinonsalo, J.: Vertical and seasonal dynamics of fungal communities in boreal Scots pine forest soil, FEMS Microbiol. Ecol., 92, fiw170, doi:10.1093/femsec/fiw170, 2016.

Schade, G. W. and Crutzen, P. J.: Emission of aliphatic-amines from animal husbandry and their reactions: potential source of, J. Atmos. Chem., 22, 319-346, 1995.

Schjoerring, J. K., Husted, S., and Poulsen, M. M.: Soil-plantatmosphere ammonia exchange associated with Calluna vulgaris and Deschampsia flexuosa, Atmos. Environ., 32, 507-512, 1998.

Schuepp, P. H.: Turbulent transport at the ground: on verification of a simple predictive model, Bound.-Lay. Meteorol., 12, 171-186, 1977.

Seinfield, J. H. and Pandis, S. N.: Atmospheric Chemistry and Physics - from air pollution to climate change, A WileyInterscience publications, New York, USA, 1998.

Silva, P. J., Erupe, M. E., Price, D., Elias, J., Malloy, Q. G. J., Li, Q., Warren, B., and Cocker III, D. R.: Trimethylamine as precursor to secondary organic aerosol formation via nitrate radical reaction in the atmosphere, Environ. Sci. Technol., 42, 4689-4696, 2008.

Sintermann, J. and Neftel, A.: Ideas and perspectives: on the emission of amines from terrestrial vegetation in the context of new atmospheric particle formation, Biogeosciences, 12, 3225-3240, doi:10.5194/bg-12-3225-2015, 2015.

Sipilä, M., Sarnela, N., Jokinen, T., Junninen, H., Hakala, J., Rissanen, M. P., Praplan, A., Simon, M., Kärten, A., Bianchi, F., Dommen, J., Curtius, J., Petäjä, T., and Worsnop, D. R.: Bisulfate - cluster based atmospheric pressure chemical ionization mass spectrometer for high-sensitivity $(<100 \mathrm{ppqV})$ detection of atmospheric dimethyl amine: proof-of-concept and first ambient data from boreal forest, Atmos. Meas. Tech., 8, 4001-4011, doi:10.5194/amt-8-4001-2015, 2015. 
Smith, J. N., Barsanti, K. C., Friedli, H. R., Ehn, M., Kulmala, M., Collinsons, D. R., Scheckman, J. H., Williams, B. J., and McMurry, P. H.: Observation of aminium salts in atmospheric nanoparticles and possible climatic implications, P. Natl. Acad. Sci. USA, 107, 6634-6639, 2009.

Starr, M., Lindroos, A.-J., and Ukonmaanaho, L.: Weathering release rates of base cations from soils within a boreal forested catchment: variation and comparison to deposition, litterfall and leaching fluxes, Environ. Earth Sci., 72, 5101-5111, 2014.

Sutton, M. A., Burkhart, J. K., Guerin, D., Nemitz, E., and Fowler, D.: Development of resistance models to describe measurements of bi-directional ammonia surface-atmosphere exchange, Atmos. Environ., 32, 473-480, 1998.

Talbot, J. M. and Treseder, K. K.: Controls over mycorrhizal uptake of organic nitrogen, Pedobiologia, 53, 169-179, 2010.

Wallander, H., Nilsson, L. O., Hagerberg, D., and Bååth, E.: Estimation of the biomass and seasonal growth of external mycelium of ectomycorrhizal fungi in the field, New Phytol., 151, 753-760, 2001.

Warren, C. R.: High diversity of small organic N observed in soil water, Soil Biol. Biochem., 57, 444-450, 2013.
Warren C. R.: Response of organic N monomers in sub-alpine soil to a dry-wet cycle, Soil Biol. Biochem., 77, 233-242, 2014.

Yan, F., Schubert, S., and Mengel, K.: Soil pH increase due to biological decarboxylation of organic anions, Soil Biol. Biochem., 28, 617-624, 1996.

You, Y., Kanawade, V. P., de Gouw, J. A., Guenther, A. B., Madronich, S., Sierra-Hernández, M. R., Lawler, M., Smith, J. N., Takahama, S., Ruggeri, G., Koss, A., Olson, K., Baumann, K., Weber, R. J., Nenes, A., Guo, H., Edgerton, E. S., Porcelli, L., Brune, W. H., Goldstein, A. H., and Lee, S.-H.: Atmospheric amines and ammonia measured with a chemical ionization mass spectrometer (CIMS), Atmos. Chem. Phys., 14, 12181-12194, doi:10.5194/acp-14-12181-2014, 2014.

Yu, H., McGraw, R., and Shan-Hu, L.: Effects of amines on formation of sub- $3 \mathrm{~nm}$ particles and their subsequent growth, Geophys. Res. Lett. 39, L02807, doi:10.1029/2011GL050099, 2012.

$\mathrm{Xu}, \mathrm{J}$. M., Tang, C., and Chen, Z. L.: The role of plant residues in $\mathrm{pH}$ change of acidic soils differing in initial $\mathrm{pH}$, Soil Biol. Biochem., 38, 709-719, 2006. 